\title{
Chemical and Sensorial Characterization of Tropical Syrah Wines Produced at Different Altitudes in Northeast of the Brazil
}

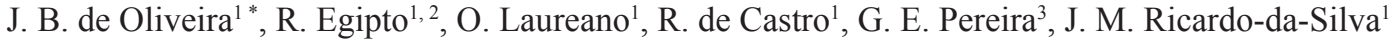

(1) LEAF-Linking Landscape, Environment, Agriculture and Food - Instituto Superior de Agronomia, Universidade de Lisboa, Tapada da Ajuda, 1349-017 Lisboa, Portugal.

(2) INIAV, I.P., Pólo de Dois Portos, Quinta da Almoínha, 2565-191 Dois Portos, Portugal

(3) Brazilian Agricultural Research Corporation Embrapa Grape \& Wine, Rua Livramento 515, 130, 95.701-008, Bento Gonçalves-RS, Brazil.

Submitted for publication: July 2018

Accepted for publication: January 2019

Keywords: altitude tropical region, organic acids, phenolic compounds, semi-arid tropical region, Syrah.

Over the years, viticulture has expanded to new regions outside the temperate zones, such as Northeast Brazil, India, Thailand, Myanmar, Vietnam, Bangladesh and Venezuela, characterized by the production of tropical wines. It is important for the productive sector to comprehend the effects of grapevine interaction with the characteristics of each new region on wines composition. In this study, the composition of wines of Syrah from two regions with different altitudes in Northeast Brazil were analyzed by different methodologies to characterize chemical compounds as sugar, acids, minerals, phenolics (anthocyanins, flavonols, stilbenes and condensed tannins) and the sensory profile. The wines of the Bahia region (1100 $\mathrm{m}$ of altitude) obtained high concentrations for chemical parameters related to color, monomeric anthocyanins, stilbenes and monomeric and oligomeric tannins. Wines of the low altitude region, Pernambuco (350 $\mathrm{m}$ of altitude) were characterized by higher concentrations of flavonols (kaempferol, isorhamnetin, quercetin and rutin) and polymerized tannins. The chemical composition of wines from the two studied regions was influenced by altitude. A trend towards higher concentrations in most for phenolic compounds analyzed was observed in wines from the higher altitude region during the two years of study. Regarding the sensory profile, fruity, floral, herbaceous and empyreumatic attributes aromatic obtained highest scores in wines of the $350 \mathrm{~m}$ altitude region, the other attributes were dependent on the year of harvest.

\section{INTRODUCTION}

The traditional wine production in the world is located in temperate regions, between the $30-45^{\circ}$ parallels in the Northern Hemisphere and between $29-42^{\circ}$ in the Southern Hemisphere (Tonietto \& Carbonneau, 1999). The knowledge of the physiology of the vine and the advances of the techniques of viticulture allowed the expansion of the production of grapes and wines to the regions located between the tropics, denominated regions of tropical viticulture (Tonietto \& Pereira, 2011).

In the northeast of Brazil, in the Sub-middle region of the São Francisco Valley, the production of wines with Vitis vinifera $\mathrm{L}$. varieties has been notable. It is located between parallels $8-9^{\circ}$ of the Southern Hemisphere, with an altitude of $350 \mathrm{~m}$, has a semi-arid tropical climate (average annual temperature of the region is $26{ }^{\circ} \mathrm{C}$ ). The soil and climatic characteristics allow staggering the production of grapes for wines throughout the year and a vine produces two annual harvest, mainly due to high temperatures, high insolation rates and water available in abundance for irrigation (Pereira et al., 2008a; Lima et al., 2011).

Another region of Northeast Brazil that is investing in the production of Vitis vinifera L. grapes is Morro do Chapéu, in state Bahia, located at $11^{\circ} 33 \mathrm{~S}$ and $41^{\circ} 09 \mathrm{~W}$ in the Chapada Diamantina, at $1100 \mathrm{~m}$ of altitude, where climatic conditions can be classified as tropical at altitude (average annual temperature is $19^{\circ} \mathrm{C}$ ). In this region studies are being carried out on grapevines adaptation and wines production, as a new alternative for the development of agriculture and industry. Unlike the region of the São Francisco Valley, the production of grapes at Morro do Chapéu occurs only once a year, due to rainy periods during the winter in this region.

Some authors have studied the composition of wines

\footnotetext{
*Corresponding author: E-mail address: juliane.barreto@hotmail.com

Acknowledgements: This research was supported by Brazilian companies: Coordenação de Aperfeiçoamento de Pessoal de Nivel Superior (Capes 6070/1302); Embrapa Semi-arid; CNPq project (403438/2013-6); Rio Sol - Global Wines (Pernambuco) and Coordination of the implementation project of Vines in Morro do Chapéu (Bahia)

In Portugal, we thank the research center in Instituto Superior de Agronomia: Linking Landscape, Environment, Agriculture and Food - LEAF (UID/ AGR/ 04129/2013) and FCT by scholarship of Egipto, R. (SFRH / BD / 128847/2017)
} 
in a tropical region: Jirayus et al. (2007) after evaluating five red wines among them Syrah, in Thailand, detected high concentrations of trans-resveratrol and gallic acid; Fernández et al. (2009) in a study with commercial wines in Venezuela, found high levels of minerals potassium, calcium, magnesium and sodium; Satisha et al. (2013) in the study of the influence of management practices on fruit composition and wine cultivation in the semi-arid tropical region of India, concluded that in tropical semi-arid conditions the concentration of tartaric acid and anthocyanins may decrease meanwhile the acid malic and potassium content may increase; Pereira et al. (2011) determined the physicochemical and aromatic characteristics of some tropical wines elaborated in Northeast Brazil, identified high concentrations of 2 methyl-1-butanol in Tempranillo and Syrah wines, methanol and 1-propanol in Petit Verdot, 1-propanol in Chenin Blanc and ethyl acetate in Sauvignon Blanc; Oliveira et al. (2012) when evaluating the influence of harvest, clone and rootstock on the chemical characteristics of tropical Syrah wine, found higher concentrations of myricetin, quercetin and kaempferol in wines made with clones in less vigorous rootstocks, as well as high concentrations of anthocyanins in grape wines of clone 525 (in rootstock IAC 313).

Tropical wines are considered recent in the current wine world, which represents a break in the pattern in world oenology. Since it is a few years old activity, when compared to the traditional producing regions, the potential of typicity, composition and quality of the wines is not yet fully unveiled. Considering the above and in the absence of publications with comparative studies on the composition of the wine elaborated with Syrah grapes, of tropical conditions with different altitudes in Northeastern Brazil, this work aims to carry out a broad characterization of these wines using different methodologies.

\section{MATERIALS AND METHODS}

\section{Characterization of vineyards and grapes}

The vineyards are located in two regions of the Brazilian Northeast, Morro do Chapéu (1100 m of altitude) in the Bahia and in the municipality of Lagoa Grande, in Pernambuco ( $350 \mathrm{~m}$ of altitude). The soils of the two areas are classified in argisols red-yellow in the region of Lagoa Grande and latosols red-yellow in Morro do Chapéu (Embrapa Solos, 2006).

Grapes "Vitis vinifera L." of the Syrah variety were harvested at both sites, the plants are cultivated in a trellis system and irrigated by drip irrigation. The vines of the region of Pernambuco are older (with an average of 10 years) and have two productive pruning. Vines from the highest altitude region are only four years old (in the first harvest of the study) and one annual production due to rainy periods at one time of the year. The grapes were harvested in the region of Bahia in September, year of 2014 (composition of the grape at harvest: $\mathrm{pH} 3.66$; total soluble solids 21.2 ${ }^{\circ}$ Brix; total acidity $5.8 \mathrm{~g} \mathrm{~L}^{-1}$ of tartaric acid) and in October of 2015 (pH 3.76; total soluble solids $21.5^{\circ}$ Brix; total acidity $5.1 \mathrm{~g} \mathrm{~L}^{-1}$ of tartaric acid). In Pernambuco, the harvests were in the months of December of 2014 (pH 4.29; total soluble solids $20.9^{\circ}$ Brix; total acidity $5.6 \mathrm{~g} \mathrm{~L}^{-1}$ of tartaric acid) and September of 2015 (pH 3.44; total soluble solids $18.2^{\circ}$ Brix; total acidity $6.4 \mathrm{~g} \mathrm{~L}^{-1}$ of tartaric acid), respectively. In each year and in both places, $40 \mathrm{~kg}$ of grapes were collected manually, in marked plants of different rows ( 25 vines) in the vineyard and in good sanitary condition and transported with plastic boxes. The decision of the harvest point was defined by the winery.

\section{Production steps of monovarietal Syrah wines}

The wines were elaborated, on an experimental scale (a sample composed of forty $\mathrm{kg}$ ), the elaboration of the wines followed the traditional vinification for red wines, with the following steps: after harvesting, the grapes were guarded in a cold room $\left(0-5^{\circ} \mathrm{C}\right)$ until vinified, it was removed from the stalks of the grapes with a semi-automatic equipment (Model DH150-DA, Recifer-Brazil), then $50 \mathrm{mg} \mathrm{L}^{-1}$ of sulfur dioxide and $20 \mathrm{~g} \mathrm{hL}^{-1}$ of yeast (Saccharomyces cerevisiae, bayanus strain - Everintec, Italy) were added for the alcoholic fermentation which occurred at the temperature between 22 to $25^{\circ} \mathrm{C}$, the "remontage" was performed once a day with rack and return modality, the maceration time, the contact of the solid parts with the liquid, uniform in all treatments of seven days, with the intention of maintaining homogeneity of the extraction of the phenolic compounds. The end of the alcoholic fermentation was identified through the stability in the value of the density and analysis of alcohol content. The malolactic fermentation was without addition of bacteria, only with the native species, with temperature varying between 16 to $18^{\circ} \mathrm{C}$, identifying the end through paper chromatography (OIV, 2014). A tartaric stabilization in cold $\left(0-5^{\circ} \mathrm{C}\right)$ was for 30 days, the amount of sulfur dioxide was corrected and then bottled in green bottles and the head space was replaced with nitrogen before closing. The wines elaborated were stored in the temperature of $16 \pm 2^{\circ} \mathrm{C}$.

\section{Classical chemical analysis}

Wines were analyzed six months after the end of the tartaric stabilization, which the following classic parameters were evaluated: $\mathrm{pH}$, total and volatile acidity, alcohol content, dry extract, free and total sulfur dioxide; residual sugar; minerals; paper chromatography (to accompany the malolactic fermentation) using the methods of OIV (2014).

In addition to spectrophotometric analysis: total anthocyanins (Somers \& Evans, 1977); colored anthocyanin (Somers \& Evans, 1977); total phenols (Ribéreau-Gayon, 1970); flavonoids and non-flavonoids (Kramling \& Singleton, 1969); color intensity and tonality (OIV, 2014); total and polymeric pigments (Somers, 1971; Somers \& Evans, 1977) and tanning power (De Freitas \& Mateus, 2001), were performed according to the methods proposed and described in the references.

\section{Quantification by high performance liquid chromatography of organic acids}

The quantification of tartaric, malic, citric, lactic, acetic and succinic acids was performed by high performance liquid chromatography (HPLC) as described by Natividade et al. (2013) and using a chromatograph coupled with a diode detector (DAD) model Aliance e2695, Milford, USA. The pulp and wine samples were filtered through a $0.45 \mu \mathrm{m}$ membrane and injected in triplicate. For determination, the 
DAD wavelength was maintained at $210 \mathrm{~nm}$, with a run time of $15 \mathrm{~min}$, flow rate $0.6 \mathrm{~mL} \mathrm{~min}{ }^{-1}$, temperature at $26^{\circ} \mathrm{C}$ and volume injection of $10 \mu \mathrm{L}$. The column used was a GeminiNX C18 (150 mm x $4.60 \mathrm{~mm}$, with internal particles $3 \mu \mathrm{m})$ and Gemini-NX C18 pre-columns (4.0 $\mathrm{mm}$ x $3.0 \mathrm{~mm})$ both from Phenomenex, USA. The mobile phase comprised of a $0.025 \mathrm{M} \mathrm{KH}-\mathrm{PO}_{4}$ solution acidified with $\mathrm{H}_{3} \mathrm{PO}_{4}$ to $\mathrm{pH}$ 2.6. The identification and quantification were performed based on standard curve using commercial standards of the corresponding acids.

Separation and quantification of monomeric anthocyanins by HPLC

For separation of the monomeric anthocyanins, a PerkinElmer HPLC (USA) was used, consisting of pump (Series 200) and detector (LC95 Uv/Visible), the separation occurred in a column C18 (250 $\mathrm{mm} \times 4 \mathrm{~mm})$, of reverse phase with $5 \mu \mathrm{m}$ of compaction, protected by a pre-column consisting of the same material, both from LichroCart, Merck-Germany. The solvents consisted of: A (40\% formic acid), B (acetonitrile PA) and C (bidistilled water). Methanol / bidistilled water $(50: 50 \mathrm{v} / \mathrm{v})$ was used to wash the column after the analyses. The initial conditions used were: $25 \% \mathrm{~A}, 6 \% \mathrm{~B}$ and $69 \% \mathrm{C}$ for $15 \mathrm{~min}$, followed by a $25 \%$ linear gradient of A, $25.5 \% \mathrm{~B}$ and $49.5 \% \mathrm{C}$ for $70 \mathrm{~min}$. The finishing with $20 \mathrm{~min}$ of $25 \%$ $\mathrm{A}, 25.5 \% \mathrm{~B}$ and $49.5 \% \mathrm{C}$. The flow was $0.7 \mathrm{~mL} \mathrm{~min}^{-1}$, using a detector with wavelength at $520 \mathrm{~nm}$. Both the samples and the solvents were filtered under the same conditions. The volume injected was $20 \mu \mathrm{L}$ and the analyzes were performed in triplicate at a temperature between 20 to $25^{\circ} \mathrm{C}$. Identification followed the method described by Roggero et al. (1986) and quantification based on the standard malvidin curve.

\section{Separation and quantification of individual flavonols and stilbene by HPLC}

Flavonols and stilbene were determined by HPLC on a Waters, USA (model Aliance e2695), chromatograph equipped with solvent pump and automatic injector, coupled with DAD, according to the methodology described by Natividade et al. (2013).

Data collection and analysis were performed using

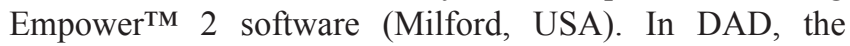
detection of the compounds was performed at $320 \mathrm{~nm}$ for trans-resveratrol and $360 \mathrm{~nm}$ in the analysis of flavonols: kaempferol 3-O-glucoside, myricetin 3-O-glucoside, quercetin-3-O-glucoside, rutin (quercetin-3-O-rutiniside) and isorhamnetin 3-O-glucoside. The column used was a Gemini-NX C18, $150 \mathrm{~mm}$ x $4.60 \mathrm{~mm}$, with internal particles $3 \mu \mathrm{m}$, and the pre-column was a Gemini-NX C18, $4.0 \mathrm{~mm} \mathrm{x}$ $3.0 \mathrm{~mm}$, both made by PhenomenexOे. The oven temperature was maintained at $40^{\circ} \mathrm{C}$, the injection volume of $10 \mu \mathrm{L}$ (the wine being previously filtered through a $0.45 \mu \mathrm{m}$ membrane)

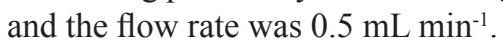

The mobile phase consisted of a solution $0.85 \%$ phosphoric acid (Solvent A) and acetonitrile (solvent B). The elution gradient was: $100 \% \mathrm{~A} ; 0-10 \mathrm{~min}$ : $93 \% \mathrm{~A}$ and $7 \% \mathrm{~B} ; 20 \mathrm{~min}: 90 \% \mathrm{~A}$ and $10 \% \mathrm{~B}, 30 \mathrm{~min}: 88 \% \mathrm{~A}$ and $12 \%$ B; 40 min: $77 \% \mathrm{~A}$ and $33 \% \mathrm{~B}$; $45 \mathrm{~min}$ : $65 \% \mathrm{~A}$ and $35 \% \mathrm{~B}$ and $55 \mathrm{~min}: 100 \% \mathrm{~B}$. The identification and quantification were performed based on standard curve using commercial standards of the corresponding flavonols.

Separation of proanthocyanidins in Sep-Pak C18 cartridges and quantification of the obtained fractions by the vanillin assay

The fractionation of the flavanols was performed using a SepPak C18 cartridge (Waters, USA) according to their degree of polymerization in three fractions; monomeric, oligomeric and polymeric, respectively, following the method described by Sun et al. (1998a). The 3-flavanol content of each fraction was determined using the vanillin assay according to the method described by Sun et al. (1998b). The quantification is performed by means of standard curves prepared from 3-flavanol monomers, oligomers and polymers of grape seed isolates and as described by Sun et al. (1998 a, b); Sun et al. (2001). The separation was performed in triplicate for each sample.

Fractionation of low molecular weight flavanols into a polyamide column chromatography and further quantification by HPLC

Five milliliters of wine were fractionated on a polyamide column (Macherey-Nagel, Germany) as described by Ricardo-da-Silva et al. (1990) phenolic acids and other interferents compounds were first eluted with $80 \mathrm{~mL}$ of phosphate buffer, $\mathrm{pH}$ 7.0. The monomeric flavanols were eluted with $50 \mathrm{~mL}$ of ethyl acetate / water $(30: 70 \mathrm{v} / \mathrm{v})$ and small oligomeric procyanidins with $50 \mathrm{~mL}$ of acetone / water $(75: 25 \mathrm{v} / \mathrm{v})$. The fractions were brought to dryness, dissolved in $1.2 \mathrm{~mL}$ of methanol / water $(50: 50 \mathrm{v} / \mathrm{v})$, filtered through a $0.45 \mu \mathrm{m}$ membrane and finally injected onto the HPLC column. The new polyamide column was used for each preparation, with three replicates per sample. After column separation of polyamide, as described above, an HPLC equipment was used for analysis, consisting of a UV-Vis detector (Waters 2487) and a Merck L-7100 pump. Separation was performed on a $\mathrm{C} 18$ reverse phase column (LichroCart, Merck, Germany), dimensions $250 \mathrm{~mm} \mathrm{x}$ $4.6 \mathrm{~mm} \times 5 \mu \mathrm{m}$, at room temperature $\left(25^{\circ} \mathrm{C}\right)$.

For monomeric flavan-3-ols, a gradient consisting of solvent A (water / acetic acid, 97.5: 2.5, v/v) and solvent B (acetonitrile / solvent A, 80:20, v/v) was applied at a flow rate of $0.9 \mathrm{~mL} \mathrm{~min}^{-1}$ as follows: $7-25 \% \mathrm{~B}$ linear from 0 to $31 \mathrm{~min}$, followed by washing (methanol / water, 50:50 v/v) 32-50 min and the rebalancing of the column from 51 to $65 \mathrm{~min}$ under initial gradient conditions. For oligomeric procyanidins, a solvent gradient A (bidistilled water) and solvent B (bidistilled water / acetic acid, 90:10 v/v) was applied at a flow rate of $1.0 \mathrm{~mL} \mathrm{~min} \mathrm{~m}^{-1}$ as follows: $10-70 \%$ linear B 0-45 $\mathrm{min}, 70-90 \%$ linear B $45-70 \mathrm{~min}, 90 \% \mathrm{~B}$ isocratic 70-82 min, $90-100 \%$ linear B 82-85 min, 100\% B isocratic 85-90 min, followed by washing (methanol / water, 50:50 v/v) 91-100 min. And rebalancing the column from 101 to 120 min under initial conditions of the gradient. The detection being carried out at $280 \mathrm{~nm}$ and injections in triplicate.

The following flavanol molecules have been quantified: gallocatechin; (+)-catechin; (-)-epicatechin; (-) epigallocatechin; procyanidin dimers B1, B2, B3 and B4, $\mathrm{B} 1$-3-O-gallate, $\mathrm{B} 2-3-O$-gallate, $\mathrm{B} 23^{3}$ - $O$-gallate, trimer $\mathrm{C} 1$ and trimer $\mathrm{T} 2$. The identification of the compounds was done 
according to the works of Rigaud et al. (1991) and Ricardoda-Silva et al. (1991a) and later confirmed by Monagas et al. (2003). The quantification of monomeric flavan-3-ol and small oligomeric procyanidins (some dimers and trimers) were based on standard curves obtained with $(+)$ catechin for the monomers and dimer B2 for the other compounds.

\section{Characterization of the sensory profile of wines}

Sensory evaluation was conducted in the sensory analysis laboratory of the Instituto Superior Agronomia in Lisbon by a panel of 12 oenology professionals, seven male and five females (from 22 to 55 years old). The panel was not trained for this study of sensory since they were professionals and were familiar with rating of the specific attributes.

The evaluation of the visual, olfactory and taste characteristics of the wines was carried out with Descriptive Analysis (DA), with 16 attributes: 4 visual sensations (color, color intensity, limpidity and fluidity), 5 aromatic attributes (fruity, floral, herbaceous, spices and empireumatic) and 7 taste attributes (sweetness, acidity, alcohol, bitterness, astringency, body and persistence). Being quantified by a scale with an unstructured intensity of 10 points, with minimum anchorage on the left and maximum on the right.

Each taster evaluated 2 samples per session, with two sections, one in the first half of 2015 (referring to wines from the 2014 harvest) and another in the first half of 2016 (wines from the 2015 harvest). The test room was composed of individual, white, illuminated booths. The volume of $50 \mathrm{~mL}$ of wine was individually served, randomising the sample position across tasters, in coded tasting glasses (ISO NORM $3591,1977)$ with random 3-digit codes and temperature of $18^{\circ} \pm 2^{\circ} \mathrm{C}$ (considered ideal for tasting red wines).

\section{Statistical analysis}

All chemical analyses of this study were performed in triplicate, to verify the differences between the samples, based on the two altitudes, an analysis of variance test (OneWay, ANOVA) and Principal Component Analysis (PCA) were determined. In the sensory analysis, an ANOVA test with 2-way of variation (samples and tasters) was performed. The Tukey test (HSD) with a significance level of 5\% was used for chemical analysis and sensory profile. Both analyses were performed in STATISTIX 9.0 software (Florida, USA).

\section{RESULTS AND DISCUSSION}

\section{Classic analysis}

The results of the classic analysis are found in Table 1, there were significant differences $(p \leq 0.05)$ in the chemical parameters analyzed between the two wine regions. The $\mathrm{pH}$ levels in all wine samples presented relatively high average values (Table 1), being from 3.84 to 4.32 in the region of highest altitude and 3.93 to 4.15 in the low altitude. According to Soares and Leão (2009), the soil-climatic conditions of region of the "São Francisco Valley", low altitude, prevail over the extraction of potassium, favoring high $\mathrm{pH}$ in wines also made with other grape varieties in this region. $\mathrm{pH}$ values between 3.6 and 4.5 have been observed in this region, which can be attributed to excessive soil fertilization with potassium fertilizers or even to the high natural concentration of this element in the soils of the region. High
$\mathrm{pH}$ values in the regions of $1100 \mathrm{~m}$ altitude (4.32) and $350 \mathrm{~m}$ altitude (4.15) in the year 2014, may also be related to high potassium concentration in this harvest (Table 1).

The concentrations of total acidity in the wines varied with the harvest, being the year of 2014 with higher values, both in the region of higher altitude (Bahia) and in the lower altitude (Pernambuco), with values of $6.4 \mathrm{~g} \mathrm{~L}^{-1}$ and $5.7 \mathrm{~g}$ $\mathrm{L}^{-1}$ of tartaric acid, respectively. The highest total acidity content, in the higher-altitude $(1100 \mathrm{~m})$ region, may be related to high concentrations of succinic acid (Table 1). According to Coulter et al. (2004) higher concentration of succinic acid may result in a remarkable increase in acidity. However, the high total acidity in the $350 \mathrm{~m}$ altitude region, in 2014, due higher concentrations of malic, lactic and acetic acids present in these wines (Table 1).

The alcohol content varied from 11.6 to $12.3 \mathrm{v} / \mathrm{v} \%$ in the states of Bahia and Pernambuco, in the years 2015 and 2014, respectively, the amount of alcohol in the wine depends on the concentration of initial sugar in the berries and the conditions under which alcoholic fermentation occurs (yeast, temperature, type of wine to be elaborated, among other factors).

\section{Organic acids}

Concentrations of tartaric acid in wines ranged from $1905.9 \mathrm{mg} \mathrm{L}^{-1}$ to $3302.1 \mathrm{mg} \mathrm{L}^{-1}$, for the region of Bahia and Pernambuco (Table 1) being within the values found in the literature for wines, according to Curvelo-Garcia and Barros (2015), L (+) - tartaric acid is the specific acid of the grapes and the most important of the wine, are determinants of the values of fixed acidity and $\mathrm{pH}$, its content is present between 1500 and $4000 \mathrm{mg} \mathrm{L}^{-1}$. The highest concentrations of the tartaric acid were obtained in wines of the region at $350 \mathrm{~m}$ of altitude and are sourced grapes. In the study conditions, high concentrations may be related to the influence of climatic conditions (higher solar radiation, temperature and low thermal amplitude - data not shown), age of the plant, higher photosynthetic rate in the berries, high concentrations of calcium and potassium in this region. According to the literature, the ascorbic acid content and consequently of the tartaric acid in the grapes are influenced by some factors such as: light, time of day, plant age (Cruz-Rus et al., 2010); exposure of the bunches to the sun (DeBolt et al., 2006); formation of crystals in the berry during maturation, rendering the acid inert for metabolization (Iland \& Coombe, 1988).

Succinic acid is formed during the process of alcoholic fermentation also from malolactic fermentation in amounts well dependent on the conditions in which it occurs, as well as the composition of the medium; the concentration in wine can range from 500 to $1500 \mathrm{mg} \mathrm{L}^{-1}$ (Curvelo-Garcia \& Barros, 2015). The highest levels found in this study were in the higher altitude region with 582.0 and $481.6 \mathrm{mg} \mathrm{L}^{-1}$, in the years of 2014 and 2015, respectively.

\section{Potassium and calcium}

Regarding the macronutrient, potassium, the concentrations in the wines of the region of low-altitude, obtained contents above $2.0 \mathrm{~g} \mathrm{~L}^{-1}$ (Table 1). According to the results presented by Pereira et. al (2007), for different red wines 
TABLE 1

Classical and spectrophotometric analysis of tropical Syrah wines from regions with different altitudes.

\begin{tabular}{|c|c|c|c|c|c|}
\hline \multirow{2}{*}{$\begin{array}{l}\text { Region } \\
\text { Harvest }\end{array}$} & \multicolumn{2}{|c|}{ Bahia (1100 $\mathrm{m}$ altitude) } & \multicolumn{2}{|c|}{ Pernambuco (350 $\mathrm{m}$ altitude) } & \multirow{2}{*}{$\frac{\text { ANOVA }}{\text { (p-values) }}$} \\
\hline & 2014 & 2015 & 2014 & 2015 & \\
\hline \multicolumn{6}{|l|}{ Classic analyses } \\
\hline $\mathrm{pH}$ & $4.32^{\mathrm{a}} \pm 0.0$ & $3.84^{\mathrm{c}} \pm 0.0$ & $4.15^{\mathrm{b}} \pm 0.0$ & $3.93^{c} \pm 0.0$ & $* *$ \\
\hline Total acidity $\left(\mathrm{g} \mathrm{L}^{-1}\right)$ & $6.4^{\mathrm{a}} \pm 0.1$ & $5.2^{c} \pm 0.1$ & $5.7^{\mathrm{b}} \pm 0.0$ & $4.8^{\mathrm{d}} \pm 0.1$ & $* * *$ \\
\hline Volatile acidity $\left(\mathrm{g} \mathrm{L}^{-1}\right)$ & $0.41^{\mathrm{d}} \pm 0.0$ & $0.79^{\mathrm{a}} \pm 0.0$ & $0.65^{\mathrm{b}} \pm 0.0$ & $0.57^{\mathrm{c}} \pm 0.0$ & $*$ \\
\hline Alcohol content (v/v\%) & $11.8^{\mathrm{b}} \pm 0.1$ & $12.3^{\mathrm{a}} \pm 0.2$ & $12.3^{\mathrm{a}} \pm 0.0$ & $11.6^{\mathrm{b}} \pm 0.1$ & $*$ \\
\hline Total dry extract $\left(\mathrm{g} \mathrm{L}^{-1}\right)$ & $27.6^{\mathrm{b}} \pm 0.2$ & $24.3^{\mathrm{c}} \pm 0.0$ & $29.7^{\mathrm{a}} \pm 0.2$ & $22.8^{\mathrm{d}} \pm 0.1$ & $*$ \\
\hline Density $\left(\mathrm{g} \mathrm{cm}^{-3}\right)$ & $0.9936^{c} \pm 0.001$ & $0.9932^{\mathrm{d}} \pm 0.0003$ & $0.9953^{\mathrm{a}} \pm 0.0001$ & $0.9940^{\mathrm{b}} \pm 0.0002$ & $* * *$ \\
\hline Residual sugar (g L-1) & $1.6^{\mathrm{b}} \pm 0.4$ & $1.1^{\mathrm{c}} \pm 0.7$ & $2.6^{\mathrm{a}} \pm 0.3$ & $1.8^{\mathrm{b}} \pm 1.1$ & $*$ \\
\hline Free sulfur dioxide $\left(\mathrm{mg} \mathrm{L}^{-1}\right)$ & $25.9^{c} \pm 0.2$ & $30.3^{b} \pm 1.2$ & $33.3^{\mathrm{a}} \pm 0.0$ & $34.3^{\mathrm{a}} \pm 1.1$ & $* * *$ \\
\hline Total sulfur dioxide $\left(\mathrm{mg} \mathrm{L}^{-1}\right)$ & $36.7^{\mathrm{d}} \pm 0.2$ & $51.5^{\mathrm{b}} \pm 1.1$ & $48.1^{\mathrm{c}} \pm 0.0$ & $63.2^{\mathrm{a}} \pm 1.3$ & $* * *$ \\
\hline \multicolumn{6}{|l|}{ Organic acids $\left(\mathrm{mg} \mathrm{L}^{-1}\right)$} \\
\hline Tartaric & $2334.1^{\mathrm{c}} \pm 6.7$ & $1905.9^{d} \pm 1.8$ & $2930.2^{b} \pm 5.8$ & $3302.1^{\mathrm{a}} \pm 11.2$ & $* * *$ \\
\hline Malic & $16.3^{b} \pm 3.1$ & $12.9^{\mathrm{b}} \pm 1.2$ & $39.7^{\mathrm{a}} \pm 1.7$ & $16.6^{\mathrm{b}} \pm 1.4$ & $* * *$ \\
\hline Lactic & $2792.8^{\mathrm{a}} \pm 3.9$ & $1882.6^{\mathrm{b}} \pm 2.2$ & $3242.7^{\mathrm{a}} \pm 2.5$ & $1905.6^{\mathrm{c}} \pm 2.7$ & $*$ \\
\hline Acetic & $283.6^{\mathrm{b}} \pm 2.2$ & $166.3^{c} \pm 4.6$ & $489.3^{\mathrm{a}} \pm 11.1$ & $137.1^{\mathrm{d}} \pm 4.9$ & $* * *$ \\
\hline Citric & $64.1^{\mathrm{d}} \pm 1.6$ & $79.1^{\mathrm{c}} \pm 0.9$ & $131.3^{\mathrm{a}} \pm 0.6$ & $93.0^{\mathrm{b}} \pm 3.0$ & $* * *$ \\
\hline Succinic & $582.0^{\mathrm{a}} \pm 1.4$ & $481.6^{\mathrm{b}} \pm 9.8$ & $383.3^{\mathrm{c}} \pm 5.7$ & $408.0^{c} \pm 7.9$ & $* *$ \\
\hline \multicolumn{6}{|l|}{ Minerals (mg L $\left.\mathbf{L}^{-1}\right)$} \\
\hline Potassium & $1982.2^{b} \pm 0.7$ & $1827.8^{\mathrm{c}} \pm 1.3$ & $2423.3^{\mathrm{a}} \pm 1.6$ & $2025.1^{\mathrm{b}} \pm 2.3$ & $* *$ \\
\hline Calcium & $45.3^{c} \pm 0.9$ & $70.4^{b} \pm 0.4$ & $42.0^{\mathrm{d}} \pm 0.8$ & $80.5^{\mathrm{a}} \pm 0.2$ & $* *$ \\
\hline
\end{tabular}

*Means followed by the same letter in the lines did not differ by Tukey test at $5 \%(\mathrm{p} \leq 0.05)$. Standard deviation of triplicate analysis; n.s. (not significant); * (significant differences at a 95\% confidence level); ** (significant differences at a 99.9\% confidence level); *** (significant differences at a $99.99 \%$ confidence level).

from Northeast Brazil, with values between 1835.9 and $3671.8 \mathrm{mg} \mathrm{L}^{-1}$. In general, the grapes and wines of the Submiddle São Francisco Valley have high concentrations of potassium because some soils present high natural levels of this macronutrient, a fact related to the source material and processes of pedogenesis (Cunha et al., 2010). Another explanation for the high potassium content is the use of the rootstock, Paulsen 1103, which tend to accumulate more potassium than in not grafted vines (Walker et al., 1998).

The values identified for calcium are within those cited in the literature. ranging from 45.3 to $70.4 \mathrm{mg} \mathrm{L}^{-1}$ in the region of Bahia $(1100 \mathrm{~m})$ and 42.0 to $80.5 \mathrm{mg} \mathrm{L}^{-1}$ and Pernambuco $(350 \mathrm{~m})$, it is verified that there is no tendency in the calcium concentration for a particular region and the concentration varied in the study years. According to Amerine \& Ough (1980) and Themelis et al. (1999) calcium levels are usually found in wines ranging from 30 to 200 $\mathrm{mg} \mathrm{L}^{-1}$ and are strongly dependent on soil composition. Its presence affects some phases of the elaboration process and in high concentrations can cause precipitation after bottling and storage of wine (Amerine \& Ough, 1980). The elevated levels of cations, as well as high $\mathrm{pH}$ values of the soil have contributed to the rapid chemical evolution of the wines elaborated in the region of Sub-middle São Francisco Valley (Pereira \& Bassoi, 2008b).

\section{Total phenols, flavonoids and non-flavonoids}

The high-altitude wines, in 2014 followed by 2015, obtained the highest concentrations for the phenolic compounds here considered (Table 2): total phenols, flavonoids and non-flavonoids. Regarding total phenols, the highest concentrations were in the state of Bahia, with a minimum of $1676.9 \mathrm{mg} \mathrm{L}^{-1}$ of gallic acid (year 2015) and a maximum of $2142.9 \mathrm{mg} \mathrm{L}^{-1}$ of gallic acid (year 2014). The flavonoid compounds obtained the same behavior, with values of 1981.1 and $1486.0 \mathrm{mg} \mathrm{L}^{-1}$ of gallic acid, for the harvests of 2014 and 2015, respectively. For non-flavonoid compounds, the highest concentration was $194.7 \mathrm{mg} \mathrm{L}^{-1}$ of gallic acid for wines from 2015, a region of $1100 \mathrm{~m}$ altitude. The values found for total phenolics and flavonoids in this study, for wines of higher altitude, in 2014, were higher than those detected by Granato et al. (2010) for Brazilian Syrah 
TABLE 2

Composition and concentration of anthocyanins, flavonols and tannins in tropical Syrah wines from different regions of the Northeast in two harvests.

\begin{tabular}{|c|c|c|c|c|c|}
\hline \multirow{2}{*}{$\begin{array}{l}\text { Region } \\
\text { Harvest }\end{array}$} & \multicolumn{2}{|c|}{ Bahia (1100 $\mathrm{m}$ altitude) } & \multicolumn{2}{|c|}{ Pernambuco (350 $\mathrm{m}$ altitude) } & \multirow{2}{*}{$\frac{\text { ANOVA }}{\text { (p-values) }}$} \\
\hline & 2014 & 2015 & 2014 & 2015 & \\
\hline \multicolumn{6}{|l|}{ Global phenolic compounds } \\
\hline Total phenols (mg L-1) & $2142.9^{\mathrm{a}} \pm 0.1$ & $1676.9^{b} \pm 0.2$ & $1456.9^{c} \pm 0.2$ & $1401.8^{\mathrm{c}} \pm 0.5$ & $* * *$ \\
\hline Non-flavonoids (mg L-1) & $162.4^{\mathrm{c}} \pm 0.0$ & $194.7^{\mathrm{a}} \pm 0.1$ & $185.0^{\mathrm{b}} \pm 0.0$ & $155.9^{\mathrm{d}} \pm 0.0$ & $* *$ \\
\hline Flavonoids (mg L-1) & $1981.1^{\mathrm{a}} \pm 0.2$ & $1486.0^{\mathrm{b}} \pm 0.2$ & $1272.4^{\mathrm{c}} \pm 0.1$ & $1246.5^{\mathrm{d}} \pm 0.5$ & $* * *$ \\
\hline \multicolumn{6}{|l|}{ Color, anthocyanins and other pigments } \\
\hline Total anthocyanins (mg L-1 of malvidin) & $372.7^{\mathrm{a}} \pm 0.3$ & $340.4^{\mathrm{b}} \pm 6.1$ & $237.5^{\mathrm{d}} \pm 1.9$ & $314.3^{c} \pm 2.8$ & $* * *$ \\
\hline Colored anthocyanins ( $\mathrm{mg} \mathrm{L}^{-1}$ of malvidin) & $74.3^{\mathrm{a}} \pm 0.8$ & $50.5^{\mathrm{b}} \pm 0.8$ & $35.1^{\mathrm{d}} \pm 0.3$ & $38.4^{\mathrm{c}} \pm 0.3$ & $* * *$ \\
\hline Ionization index $(\%)$ & $19.9^{\mathrm{a}} \pm 0.3$ & $14.8^{\mathrm{b}} \pm 0.2$ & $14.5^{\mathrm{b}} \pm 0.2$ & $11.7^{\mathrm{c}} \pm 0.5$ & $* * *$ \\
\hline Total pigments (u.a) & $13.1^{\mathrm{a}} \pm 1.6$ & $11.6^{\mathrm{b}} \pm 0.9$ & $9.2^{\mathrm{d}} \pm 0.9$ & $10.6^{\mathrm{c}} \pm 1.2$ & $* *$ \\
\hline Polymerized pigment (u.a) & $4.2^{\mathrm{a}} \pm 0.2$ & $2.9^{b} \pm 0.5$ & $1.8^{\mathrm{c}} \pm 0.8$ & $1.9^{\mathrm{c}} \pm 0.3$ & $* *$ \\
\hline Polymeric pigments index (\%) & $32.1^{\mathrm{a}} \pm 1.1$ & $25.0^{\mathrm{b}} \pm 0.7$ & $19.6^{\mathrm{c}} \pm 1.0$ & $17.9^{\mathrm{d}} \pm 0.6$ & $* *$ \\
\hline Color intensity (u.a) & $16.590^{\mathrm{a}} \pm 0.067$ & $11.540^{\mathrm{b}} \pm 0.026$ & $7.900^{\mathrm{d}} \pm 0.053$ & $8.480^{c} \pm 0.081$ & $* * *$ \\
\hline Tonality (u.a) & $0.732^{b} \pm 0.002$ & $0.711^{\mathrm{c}} \pm 0.003$ & $0.753^{\mathrm{a}} \pm 0.005$ & $0.665^{\mathrm{d}} \pm 0.001$ & $* *$ \\
\hline \multicolumn{6}{|l|}{ Condensed tannins $\left(\mathrm{mg} \mathrm{L}^{-1}\right)$} \\
\hline Monomeric & $23.6^{\mathrm{a}} \pm 1.1$ & $23.9^{\mathrm{a}} \pm 1.3$ & $16.3^{\mathrm{b}} \pm 0.4$ & $12.6^{\mathrm{c}} \pm 0.4$ & $* * *$ \\
\hline Oligomeric & $159.1^{\mathrm{a}} \pm 0.7$ & $146.6^{\mathrm{b}} \pm 3.7$ & $142.5^{\mathrm{bc}} \pm 0.4$ & $139.3^{c} \pm 0.3$ & $* *$ \\
\hline Polymeric & $302.8^{c} \pm 0.9$ & $249.0^{\mathrm{d}} \pm 1.3$ & $665.4^{\mathrm{a}} \pm 1.0$ & $400.0^{\mathrm{b}} \pm 4.4$ & $* * *$ \\
\hline Total tannins & $485.5^{\mathrm{c}} \pm 1.7$ & $419.5^{\mathrm{d}} \pm 17.0$ & $824.3^{\mathrm{a}} \pm 1.2$ & $551.9^{\mathrm{b}} \pm 4.5$ & $* * *$ \\
\hline Tannin power (NTU $\left.\mathrm{mL}^{-1}\right)$ & $191.0^{c} \pm 1.8$ & $153.2^{\mathrm{d}} \pm 1.3$ & $212.1^{\mathrm{a}} \pm 2.2$ & $203.2^{\mathrm{b}} \pm 1.9$ & $* * *$ \\
\hline
\end{tabular}

*Means followed by the same letter in the lines did not differ by Tukey test at $5 \%(\mathrm{p} \leq 0.05)$. Standard deviation of triplicate analysis. Total phenols, non-flavonoids and flavonoids expressed as $\mathrm{mg} \mathrm{L}^{-1}$ of gallic acid; u.a (absorbance unit); n.s. (not significant); * (significant differences at a $95 \%$ confidence level); $* *$ (significant differences at a 99.9\% confidence level); *** (significant differences at a $99.99 \%$ confidence level).

commercial wines, in different harvests. Regarding wines, in the year 2015, of both altitudes, the contents are in agreement to the same author. The "terroir" affects to a large extent the carbon flow to the different pathways in the metabolism of flavonoids from grape berries, and finally determine the phenol profiles in wines. The lower temperatures and the greater thermal amplitude in the region of $1100 \mathrm{~m}$ compared to the region of $350 \mathrm{~m}$ seem to favor the synthesis of these compounds.

\section{Total anthocyanins, pigments and color}

The harvest of 2014 in the region of higher altitude favored the composition of wines with high concentrations of total anthocyanins (372.7 $\mathrm{mg} \mathrm{L}^{-1}$ of malvidin) and colored anthocyanins (74.3 $\mathrm{mg} \mathrm{L}^{-1}$ of malvidin). According to Liang et al. (2012) altitude, temperature and precipitation play important roles in the accumulation of anthocyanins and flavonols compounds in Vitis vinifera L. vines. These compounds are extracted rapidly from the grapes during winemaking and reach a maximum concentration in the early days.
Ionization index of anthocyanins varied from $11.7 \%$ to $19.9 \%$, being within the expected range for young wines, according to Riberéau-Gayon et al. (2006) the ionization index for young wines varies from 10 to $30 \%$ and increases during aging, reaching 80 to $90 \%$ in old wines. The highest percentage for the ionization index of anthocyanins was in the wine from the Bahia region (1100 m of altitude) with $19.9 \%$, fact that is related to higher concentrations of total anthocyanins in these samples (372.7 $\mathrm{mg} \mathrm{L}^{-1}$ of malvidin).

The total and polymerized pigments were higher in wines from the highest altitude region $(1100 \mathrm{~m})$, harvest of 2014 and 2015, respectively. High concentrations of total anthocyanins, monomeric and oligomeric tannins in wines from the $1100 \mathrm{~m}$ region may have favored anthocyanin and tannin reactions, increasing the pigmentation in these samples, these reactions already were reported by other authors (Dallas et al., 1996; Riberéau-Gayon et al., 2006; Zeng et al., 2016).

The intensity of color obtained higher value in the region of high altitude (16.60) in the 2014 harvest, already the tonality was higher in Pernambuco, harvest 2014, with 0.753 . 
The color of red wines does not only depend on anthocyanin content but is closely dependent on the physicochemical characteristics of the pigments and the environment in which they are found (Ribéreau-Gayon, 1973; Timberlake and Bridle, 1976). In this study, it is possible to correlate the wines with higher color intensity (higher altitude) being those that have higher concentrations of anthocyanins and total pigments (Table 2).

\section{Condensed tannins}

Regarding the fractionation of the tannins, there were significant differences in the wines (Table 2). The monomeric fraction was higher in the two harvests for the wine of altitude $1100 \mathrm{~m}$, with values of 23.6 and $23.9 \mathrm{mg} \mathrm{L}^{-1}$ for the years 2014 and 2015, respectively. Concentration of the oligomeric fraction was between $139.3 \mathrm{mg} \mathrm{L}^{-1}$ (Pernambuco, 2015) and $159.1 \mathrm{mg} \mathrm{L}^{-1}$ in the state of Bahia, harvest 2014. For polymeric tannins the highest concentrations were in Pernambuco (350 $\mathrm{m}$ altitude), with higher values in the 2014 harvest $\left(665.4 \mathrm{mg} \mathrm{L}^{-1}\right)$ followed by the 2015 harvest (400.0 $\mathrm{mg} \mathrm{L}^{-1}$ ). The wines from the Pernambuco region had high concentrations of total tannins, with $824.3 \mathrm{mg} \mathrm{L}^{-1}$ in harvest 2014 and $551.9 \mathrm{mg} \mathrm{L}^{-1}$ in 2015 . The monomeric and oligomeric condensed tannins of this study are below the values found by Sun et al. (1998b) in different red wines of Portuguese grape varieties; the polymers are among the concentrates found by the same author.

High concentrations of polymeric and total tannins were observed in wines from the lower altitude region, $350 \mathrm{~m}$, which may be related to a characteristic of the altitude effect, as well as the better extraction capacity of the condensed tannins from the solid parts of the grapes of this region. $\mathrm{Li}$ et al. (2011) when evaluating Cabernet Sauvignon wines at different altitudes in China also found higher concentrations of polymeric tannins in low altitude region $(214 \mathrm{~m})$ when compared to the region with an altitude of $1214 \mathrm{~m}$. The extraction capacity of wine tannins has been reported by other authors under traditional winemaking conditions (Vidal et al., 2004; Adams and Scholz, 2008; Hanlin et al., 2010), but other studies are still needed for tropical climate conditions.

In the tannin power analysis, a chemical parameter that intends to estimate the astringency of a wine (De Freitas and Mateus, 2001) the wines of low altitude obtained high concentrations ranging from 203.2 to $212.1 \mathrm{NTU} \mathrm{mL}^{-1}$, for harvests of 2015 and 2014, respectively. According to the literature, polymeric procyanidins in the concentration of 250-1000 $\mathrm{mg} \mathrm{L}^{-1}$ have a higher intensity of astringency than oligomeric procyanidins (Ribéreau-Gayon et al., 2006) the results obtained in this study are in agreement.

\section{Individual monomeric anthocyanins}

In the wines analyzed, it was possible to detect 14 anthocyanin compounds, which constitute three groups of substances: non-acylated anthocyanins 3-O-glucoside; anthocyanin esterified with acetic acid and anthocyanin esterified with p-coumaric acid. It is observed in the Table 3 that there is a variation of anthocyanins between regions, being able to be an indicator of altitude influence.

The group of monomeric anthocyanins in their
3-O-glucoside form (delphinidin, peonidin, petunidin and malvidin) obtained higher concentrations in wines from the high-altitude region, except for Cyanidin 3-O-glucoside. The cyanidin 3-O-glucoside was quantified only in the 2014 harvest in Pernambuco $\left(2.3 \mathrm{mg} \mathrm{L}^{-1}\right)$, other studies had already identified and quantified these compounds in Syrah wines as reported by Gutièrrez et al. (2005) which found 0.9 to $2.8 \mathrm{mg} \mathrm{L}^{-1}$ in Syrah wine after analysis of 0 to 9 months of bottled and Andrade et al. (2013) quantified 6.58 - $9.24 \mathrm{mg}$ $\mathrm{L}^{-1}$ in commercial wines from the São Francisco Valley and 4.7 to $10.8 \mathrm{mg} \mathrm{L}^{-1}$ in Chilean wines.

The malvidin 3-O-glucoside is actually the most abundant anthocyanin among those studied, the highest concentration was for the region of Bahia (43.2 $\left.\mathrm{mg} \mathrm{L}^{-1}\right)$. The values of malvidin in this study were lower than those found by Li et al. (2011) in a study of Cabernet Sauvignon wines of different altitudes in China in which they detected concentrations above $130 \mathrm{mg} \mathrm{L}^{-1}$.

The anthocyanins group 3-O-acetylglucoside reached higher concentrations in the wines of the Pernambuco region. A situation also found by Andrade et al. (2013) when studying Syrah red wines from the San Francisco Valley and Chile. This can be explained based on the climatic conditions of this region (warm climate with high exposure of the grape to sunlight) that collaborate with the enzymatic activity of the anthocyanin acyltransferase, responsible for converting the glucoside forms to acetylate, improving pigment stability and fruit color (Fei He et al., 2010; Andrade et al., 2013) and consequently of the wines.

In the group of anthocyanins esterified as p-coumaric acid, the highest concentrations in the region of $1100 \mathrm{~m}$ of altitude for the compounds peonidin $\left(1.7 \mathrm{mg} \mathrm{L}^{-1}\right)$, delphinidin (3.4 $\left.\mathrm{mg} \mathrm{L}^{-1}\right)$ and malvidin $\left(3.6 \mathrm{mg} \mathrm{L}^{-1}\right)$ are found in agreement with those found by Li et al. (2011) for Cabernet Sauvignon wines at altitudes of $1214 \mathrm{~m}$. However, there are no studies in the literature that prove a direct relationship between synthesis of anthocyanins coumarylated and the altitude.

In relation to the total monomeric anthocyanins, the highest concentration was for a region of $1100 \mathrm{~m}$ altitude with $71.3 \mathrm{mg} \mathrm{L}^{-1}$, in the vintage of the year 2014 . It is possible to observe that there is no tendency for higher concentrations in a specific region and that the harvest year seems to be more significant.

\section{Flavonols and stilbene}

The flavonols detected and quantified during this study (Table 3) were formed by the five flavonoid structures commonly reported for Vitis vinifera L.: kaempferol, isorhamnetin, myricetin, quercetin and rutin, each in glucosylated. The low-altitude region was highlighted with higher concentrations for most of the compounds except for myricetin 3-O-glucoside. Quercetin 3-O-glucoside obtained the highest concentration $\left(25.8 \mathrm{mg} \mathrm{L}^{-1}\right)$ among flavonols studied. This concentration was higher than those found by La Torre et al. (2006) for six commercial wines from Sicily and less than that found by Belmiro et al. (2017) for Syrah commercial wine from the São Francisco Valley, which found $125.5 \mathrm{mg} \mathrm{L}^{-1}$.

Concentrations of myricetin ranged from 1.5 to $5.0 \mathrm{mg} \mathrm{L}^{-1}$, the region of high-altitude in 2014 , obtained 
TABLE 3

Composition and concentration of anthocyanins, flavonols, stilbene, monomeric and small oligomeric procyanidins in tropical Syrah wines from different altitudes of the Northeast.

\begin{tabular}{|c|c|c|c|c|c|}
\hline \multirow{2}{*}{$\begin{array}{l}\text { Region } \\
\text { Harvest }\end{array}$} & \multicolumn{2}{|c|}{ Bahia (1100 m altitude) } & \multicolumn{2}{|c|}{ Pernambuco (350 m altitude) } & \multirow{2}{*}{$\begin{array}{l}\text { ANOVA } \\
\text { (p-values) }\end{array}$} \\
\hline & 2014 & 2015 & 2014 & 2015 & \\
\hline \multicolumn{6}{|l|}{ Monomeric anthocyanins $\left(\mathrm{mg} \mathrm{L}^{-1}\right)$} \\
\hline Cyanidin 3-O-glucoside & $0.0^{\mathrm{b}} \pm 0.0$ & $0.0^{\mathrm{b}} \pm 0.0$ & $2.3^{\mathrm{a}} \pm 0.1$ & $0.0^{\mathrm{b}} \pm 0.0$ & $* * *$ \\
\hline Delphinidin 3-O-glucoside & $1.1^{\mathrm{d}} \pm 0.2$ & $5.9^{\mathrm{a}} \pm 0.1$ & $2.3^{\mathrm{c}} \pm 0.1$ & $4.6^{b} \pm 0.5$ & * \\
\hline Peonidin 3-O-glucoside & $3.3^{\mathrm{a}} \pm 0.2$ & $3.4^{\mathrm{a}} \pm 0.1$ & $1.3^{\mathrm{b}} \pm 0.1$ & $1.6^{\mathrm{b}} \pm 0.2$ & $* * *$ \\
\hline Petunidin 3-O-glucoside & $5.2^{\mathrm{a}} \pm 0.4$ & $4.5^{b} \pm 0.3$ & $0.9^{d} \pm 0.1$ & $3.6^{c} \pm 0.1$ & $* * *$ \\
\hline Malvidin 3-O-glucoside & $43.2^{\mathrm{a}} \pm 0.6$ & $29.5^{\mathrm{c}} \pm 0.9$ & $20.9^{\mathrm{d}} \pm 1.3$ & $33.0^{\mathrm{b}} \pm 0.2$ & $* * *$ \\
\hline Peonidin 3-O-acetylglucoside & $0.0^{\mathrm{c}} \pm 0.0$ & $1.0^{\mathrm{b}} \pm 0.2$ & $1.8^{\mathrm{a}} \pm 0.1$ & $0.9^{\mathrm{b}} \pm 0.0$ & $* * *$ \\
\hline Petunidin 3-O-acetylglucoside & $1.1^{\mathrm{b}} \pm 0.1$ & $0.5^{\mathrm{c}} \pm 0.1$ & $1.5^{\mathrm{a}} \pm 0.1$ & $1.4^{\mathrm{a}} \pm 0.1$ & $* * *$ \\
\hline Cyanidin 3-O-acetylglucoside & $0.4^{\mathrm{b}} \pm 0.1$ & $0.3^{\mathrm{b}} \pm 0.0$ & $0.4^{\mathrm{b}} \pm 0.0$ & $1.1^{\mathrm{a}} \pm 0.0$ & $* * *$ \\
\hline Delphinidin 3-O-acetylglucoside & $1.2^{\mathrm{b}} \pm 0.2$ & $2.3^{\mathrm{a}} \pm 0.2$ & $1.3^{\mathrm{b}} \pm 0.1$ & $2.2^{\mathrm{a}} \pm 0.1$ & $*$ \\
\hline Malvidin 3-O-acetylglucoside & $5.4^{\mathrm{c}} \pm 0.2$ & $5.7^{\mathrm{c}} \pm 0.1$ & $12.6^{\mathrm{a}} \pm 0.1$ & $10.3^{b} \pm 0.3$ & $* * *$ \\
\hline Peonidin 3-O-coumarylglucoside & $1.1^{\mathrm{b}} \pm 0.1$ & $1.7^{\mathrm{a}} \pm 0.3$ & $0.0^{\mathrm{c}} \pm 0.0$ & $0.9^{\mathrm{b}} \pm 0.0$ & $* *$ \\
\hline Petunidin 3-O-coumarylglucoside & $0.4^{\mathrm{b}} \pm 0.1$ & $0.9^{\mathrm{a}} \pm 0.1$ & $1.1^{\mathrm{a}} \pm 0.0$ & $0.6^{\mathrm{b}} \pm 0.0$ & * \\
\hline Delphinidin 3-O-coumarylglucoside & $3.4^{\mathrm{a}} \pm 0.2$ & $2.7^{\mathrm{b}} \pm 0.2$ & $0.0^{\mathrm{c}} \pm 0.0$ & $2.3^{c} \pm 0.1$ & $* * *$ \\
\hline Malvidin 3-O-coumarylglucoside & $3.6^{\mathrm{a}} \pm 0.1$ & $2.8^{\mathrm{bc}} \pm 0.1$ & $3.0^{\mathrm{b}} \pm 0.1$ & $2.3^{\mathrm{c}} \pm 0.0$ & $*$ \\
\hline Total anthocyanins monomeric & $71.3^{\mathrm{a}} \pm 0.9$ & $61.8^{\mathrm{c}} \pm 0.9$ & $51.7^{\mathrm{d}} \pm 1.2$ & $64.1^{b} \pm 0.9$ & $* *$ \\
\hline \multicolumn{6}{|l|}{ Flavonols $\left(\mathrm{mg} \mathrm{L}^{-1}\right)$} \\
\hline Kaempferol 3-O-glucoside & $1.4^{\mathrm{b}} \pm 0.0$ & $1.10^{\mathrm{c}} \pm 0.0$ & $1.4^{\mathrm{b}} \pm 0.1$ & $3.5^{\mathrm{a}} \pm 0.0$ & $* * *$ \\
\hline Isorhamnetin 3-O-glucoside & $9.8^{\mathrm{b}} \pm 0.2$ & $4.6^{\mathrm{d}} \pm 0.0$ & $16.5^{\mathrm{a}} \pm 0.1$ & $13.9^{\mathrm{b}} \pm 0.2$ & $* * *$ \\
\hline Myricetin 3-O-glucoside & $5.0^{\mathrm{a}} \pm 0.1$ & $3.1^{\mathrm{c}} \pm 0.0$ & $1.5^{\mathrm{d}} \pm 0.1$ & $3.4^{\mathrm{b}} \pm 0.0$ & $* * *$ \\
\hline Quercetin-3-O-glucoside & $8.1^{\mathrm{c}} \pm 0.1$ & $6.0^{\mathrm{d}} \pm 0.1$ & $15.8^{\mathrm{b}} \pm 0.2$ & $25.8^{\mathrm{a}} \pm 0.8$ & $* * *$ \\
\hline Rutin (Quercetin-3-O-rutiniside) & $0.7^{b} \pm 0.0$ & $0.6^{\mathrm{b}} \pm 0.0$ & $0.5^{\mathrm{c}} \pm 0.0$ & $1.3^{\mathrm{a}} \pm 0.0$ & $* * *$ \\
\hline Total flavonols & $25.0^{\mathrm{c}} \pm 0.8$ & $15.4^{\mathrm{d}} \pm 0.1$ & $35.7^{\mathrm{b}} \pm 0.9$ & $47.9^{\mathrm{a}} \pm 1.1$ & $* * *$ \\
\hline \multicolumn{6}{|l|}{ Stilbene $\left(\mathrm{mg} \mathrm{L}^{-1}\right)$} \\
\hline Trans-resveratrol & $3.5^{\mathrm{a}} \pm 0.1$ & $2.2^{\mathrm{b}} \pm 0.0$ & $1.3^{\mathrm{d}} \pm 0.0$ & $1.7^{\mathrm{c}} \pm 0.1$ & $* * *$ \\
\hline \multicolumn{6}{|c|}{ Flavanol monomeric and small oligomeric procyanidins $\left(\mathrm{mg} \mathrm{L}^{-1}\right)$} \\
\hline$(+)$ Gallocatechin & $4.7^{\mathrm{a}} \pm 0.1$ & $0.9^{c} \pm 0.0$ & $1.6^{\mathrm{b}} \pm 0.3$ & $0.6^{\mathrm{c}} \pm 0.2$ & $* *$ \\
\hline$(+)$ Catechin & $3.5^{b} \pm 0.1$ & $1.7^{\mathrm{c}} \pm 0.1$ & $5.5^{\mathrm{a}} \pm 0.1$ & $1.5^{\mathrm{c}} \pm 0.1$ & $* * *$ \\
\hline (-) Epicatechin & $18.7^{\mathrm{a}} \pm 0.4$ & $8.8^{\mathrm{b}} \pm 0.2$ & $6.9^{c} \pm 0.0$ & $6.2^{\mathrm{d}} \pm 0.1$ & $* * *$ \\
\hline (-) Epigallocatechin & $12.4^{\mathrm{a}} \pm 0.2$ & $7.1^{\mathrm{b}} \pm 0.1$ & $3.2^{\mathrm{c}} \pm 0.4$ & $12.6^{\mathrm{a}} \pm 0.8$ & $* * *$ \\
\hline B1 & $13.8^{b} \pm 0.2$ & $3.8^{\mathrm{d}} \pm 0.1$ & $20.8^{\mathrm{a}} \pm 0.1$ & $9.0^{\mathrm{c}} \pm 0.1$ & $* * *$ \\
\hline B2 & $4.4^{\mathrm{a}} \pm 0.3$ & $1.2^{\mathrm{b}} \pm 0.0$ & $4.0^{\mathrm{a}} \pm 0.3$ & $1.3^{\mathrm{b}} \pm 0.1$ & $*$ \\
\hline B3 & $8.2^{\mathrm{a}} \pm 0.4$ & $2.7^{\mathrm{c}} \pm 0.1$ & $4.8^{\mathrm{b}} \pm 0.2$ & $1.1^{\mathrm{d}} \pm 0.2$ & $* * *$ \\
\hline B1 3-O-gallate & $2.5^{\mathrm{b}} \pm 0.2$ & $3.9^{\mathrm{a}} \pm 0.1$ & $1.9^{\mathrm{c}} \pm 0.0$ & $3.0^{\mathrm{b}} \pm 0.3$ & $* * *$ \\
\hline B2 3-O-gallate & $0.9^{\mathrm{a}} \pm 0.1$ & $0.5^{\mathrm{b}} \pm 0.1$ & $0.6^{\mathrm{b}} \pm 0.1$ & $0.1^{\mathrm{c}} \pm 0.0$ & $* *$ \\
\hline B2 3'-O-gallate & $2.5^{\mathrm{b}} \pm 0.2$ & $2.2^{\mathrm{b}} \pm 0.1$ & $6.0^{\mathrm{a}} \pm 0.1$ & $1.3^{\mathrm{c}} \pm 0.0$ & $* * *$ \\
\hline Epicatechin 3-O-gallate & $0.4^{\mathrm{a}} \pm 0.1$ & $0.3^{\mathrm{b}} \pm 0.0$ & $0.2^{\mathrm{b}} \pm 0.0$ & $0.2^{\mathrm{b}} \pm 0.0$ & $* *$ \\
\hline $\mathrm{C} 1$ & $2.9^{c} \pm 0.3$ & $0.9^{\mathrm{d}} \pm 0.0$ & $4.8^{\mathrm{b}} \pm 0.2$ & $7.8^{\mathrm{a}} \pm 0.3$ & $* * *$ \\
\hline Trimer 2 & $1.4^{\mathrm{a}} \pm 0.2$ & $0.2^{\mathrm{c}} \pm 0.0$ & $0.9^{\mathrm{b}} \pm 0.0$ & $0.0^{\mathrm{c}} \pm 0.0$ & $*$ \\
\hline Total flavanols & $76.5^{\mathrm{a}} \pm 1.4$ & $33.9^{\mathrm{d}} \pm 0.3$ & $60.2^{b} \pm 0.5$ & $45.0^{c} \pm 0.2$ & $* *$ \\
\hline
\end{tabular}

* Means followed by the same letter in the lines did not differ by Tukey test at $5 \%(\mathrm{p} \leq 0.05)$. Standard deviation of triplicate analysis. Concentrations expressed in $\mathrm{mg} \mathrm{L}^{-1}$; n.s. (not significant); * (significant differences at a $95 \%$ confidence level); $* *($ significant differences at a $99.9 \%$ confidence level); $* * *$ (significant differences at a $99.99 \%$ confidence level). 
higher value. This content is in accordance with the cited by Agatonovic-Kustrin et al. (2015) for commercial Syrah wines from Australia ( 0.0 to $9.4 \mathrm{mg} \mathrm{L}^{-1}$ ) and below the values quoted by Granato et al. (2011) for commercial wines Syrah do Brazil, Argentina and Chile, with 18.0; 40.5 and $32.1 \mathrm{mg}$ $\mathrm{L}^{-1}$, respectively.

The highest concentration analyzed of rutin in this study was $1.3 \mathrm{mg} \mathrm{L}^{-1}$, in Pernambuco, harvested in 2015. Being according to the cited in the literature: Fang Fang et al. (2008) found values of $0.0-3.7 \mathrm{mg} \mathrm{L}^{-1}$ after analysis of red wines from different varieties and regions of China. Granato et al. (2011) and Tauchen et al. (2015) when studying wines from different regions of Georgia, Czech Republic, France, Italy and Austria, identified concentrations varying from 0.9 to $4.5 \mathrm{mg} \mathrm{L}^{-1}$.

High levels of trans-resveratrol present in the wine samples were for high- altitude region, with relevance for harvest of $2014\left(3.5 \mathrm{mg} \mathrm{L}^{-1}\right)$. The results are in agreement with the literature for wines of the region with cold climate, as mentioned by Belmiro et al. (2017) with contents of 2.7 to $4.4 \mathrm{mg} \mathrm{L}^{-1}$ for Argentine wines and with Granato et al. (2011) studying Chilean and Brazilian Syrah wines (Rio Grande do Sul), cited concentrations of 3.1 and $2.8 \mathrm{mg} \mathrm{L}^{-1}$, respectively. The low-altitude Syrah wines obtained values between 1.3 and $1.7 \mathrm{mg} \mathrm{L}^{-1}$, higher than those mentioned by Padilha et al. (2016) for Syrah commercial wines from the same region. According to the literature, grape derivatives produced in tropical regions are potential sources of resveratrol, due to high temperature and light conditions, these compounds are present in cis form due to their greater chemical stability (Lucena et al., 2010). This fact explains the high concentrations in the region of lower altitude $(350 \mathrm{~m})$, indicating that in the wines from region the concentrations may be even higher.

\section{Monomeric and small oligomeric procyanidins}

The main Flavan-3-ols monomer in the wines are (+)-catechin and its isomer (-)-epicatechin, which can also be found in the form of gallic ester, verifying the presence of small amounts of epicatequin 3-O-gallate. Concentrations in this study, Table 3, of these compounds were influenced by the region. Concentrations $(+)$-catechin were higher in Pernambuco (5.5 $\mathrm{mg} \mathrm{L}^{-1}$ ) for (-)-epicatechin and (-)-epicatechin-3-Ogallate high concentrations were in wines of Bahia, with 18.7 and $0.4 \mathrm{mg} \mathrm{L}^{-1}$, respectively.

In total, 13 individual flavan-3-ol molecules were detected and quantified in all tropical Syrah wines at different altitudes by HPLC (Table 3), including monomers, dimers and trimers. There were significant differences between the tropical Brazilian wines studied, the highest concentrations for the wines of the highest altitude region, except for catechin, $\mathrm{B} 1$ dimer, B2 3'-O-gallate and $\mathrm{C} 1$ trimer. According to Sun et al. (2001) the catechins and procyanidins of skins may be of greater critical importance in wines because of their location in the tissues, since they can be readily released during the maceration phase in the elaboration process. Extraction is influenced by the concentration of proanthocyanidins in the skin, the composition of the cell walls of the berry, which clearly affects the extraction capacity and processing methods (Ortega-Regules et al.,
2006). On the other hand, it has generally been accepted that the extraction of proanthocyanidins from the seeds requires longer maceration time because the lipids present in the seed should be eliminated first, which is usually done by increasing concentrations of ethanol (Glories \& Saucier, 2000).

Among the procyanidins of the wine, B1 dimer has been found to have a higher content, according to previous studies (Ricardo-da-Silva et al., 1992; Monagas et al., 2003). The concentrations of B1 found under tropical conditions were lower than those reported by Leeuw et al. (2014) for Syrah wines in different regions of France (found from 45.83 to $\left.70.56 \mathrm{mg} \mathrm{L}^{-1}\right)$.

Regarding total flavanols, concentrations in the highest altitude region $(1100 \mathrm{~m})$ ranged from 33.9 to $76.5 \mathrm{mg} \mathrm{L}^{-1}$, while in the low altitude region $(350 \mathrm{~m})$ they ranged from 45.0 to $60.2 \mathrm{mg} \mathrm{L}^{-1}$, the effect harvest season seems to be more significant than the region. According to Revilla et al. (1997) the climatic conditions and year to year can affect the total amount of catechins and procyanidins in grapes and consequently wines.

\section{Principal component analysis (PCA)}

The principal component analysis of the data matrix (chemical analysis vs. wines) was carried out to find relevant sources of variability and to highlight the relationships between the effects of altitude and on the phenolic composition harvest of tropical Syrah wines. The analysis of the main components applied on anthocyanins and flavonols is shown in Fig. 1. As can be seen, the main component 1 (PC1) represents $25.97 \%$ of the total variability of the original data and the second $50.70 \%$ (PC2), that is, together $76.67 \%$ of the total variance. Throughout the first component (PC1) there are three groups of larger sizes, corresponding to the Pernambuco wines (harvest 2015), Bahia (in the two years of harvest) and Pernambuco harvest of 2014. The group of high altitude wines, harvest 2014, is superimposed on the wine group from the 2015 harvest. This result is possibly due to the fact that there are significant similarities in concentrations of anthocyanins 3-O-coumarylglucoside in these two groups, such as cyanidin, malvidin and peonidin according to PCA. The discrimination between the three groups does not occur in the second component (PC2), where there is the formation of two groups only, broken down by region, in the positive axis Pernambuco and negative Bahia.

An inspection on the loadings chart, Fig. 1B, shows that the separation of wines in $\mathrm{PC} 1$ (negative axis) is essentially determined by the parameter sets: Malvidin 3-O-coumarylglucoside, cyanidin 3-O-coumarylglucoside, resveratrol, cyanidin 3-O-glucoside, petunidin 3-O-coumarylglucoside, Peonidin 3-O-acetylglucoside. The positive side being influenced by the other compounds. The second component PC2 (positive axis) is related to the variables cyanidin 3-O-acetylglucoside, petunidin 3-O-acetylglucoside, malvidin 3- $O$-acetylglucoside, peonidin 3-O-acetylglucoside, petunidin 3-O-coumarylglucoside, cyanidin 3-O-glucoside, quercetin, isorhamnetin and kaempferol.

The main component analysis (PCA) applied on the result of tannins means and flavanols in wines in the two 


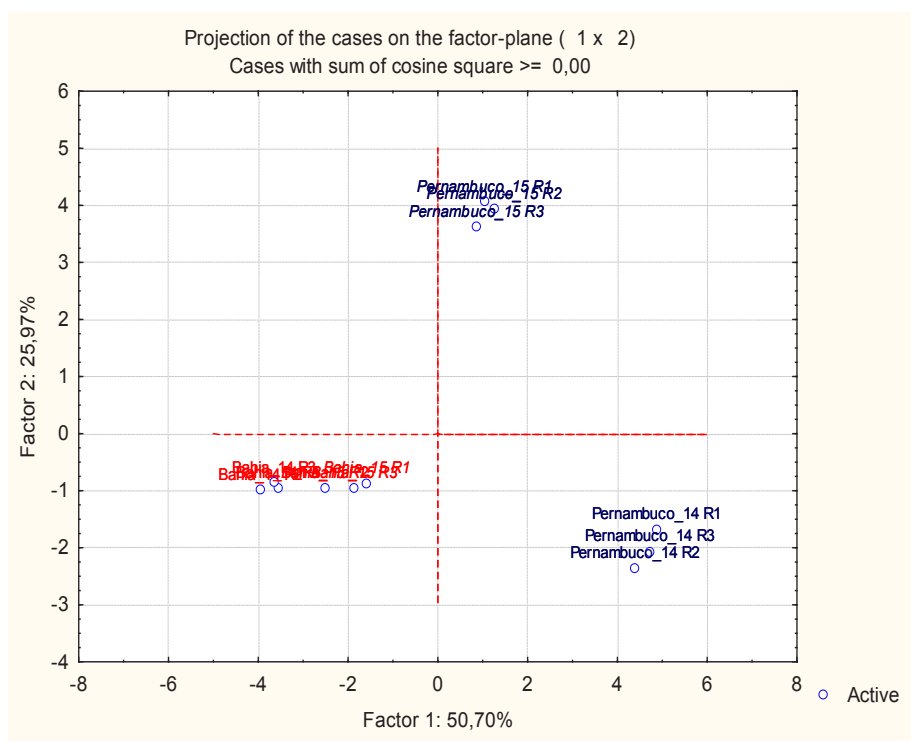

Figure 1A. Wine variation in PCA.

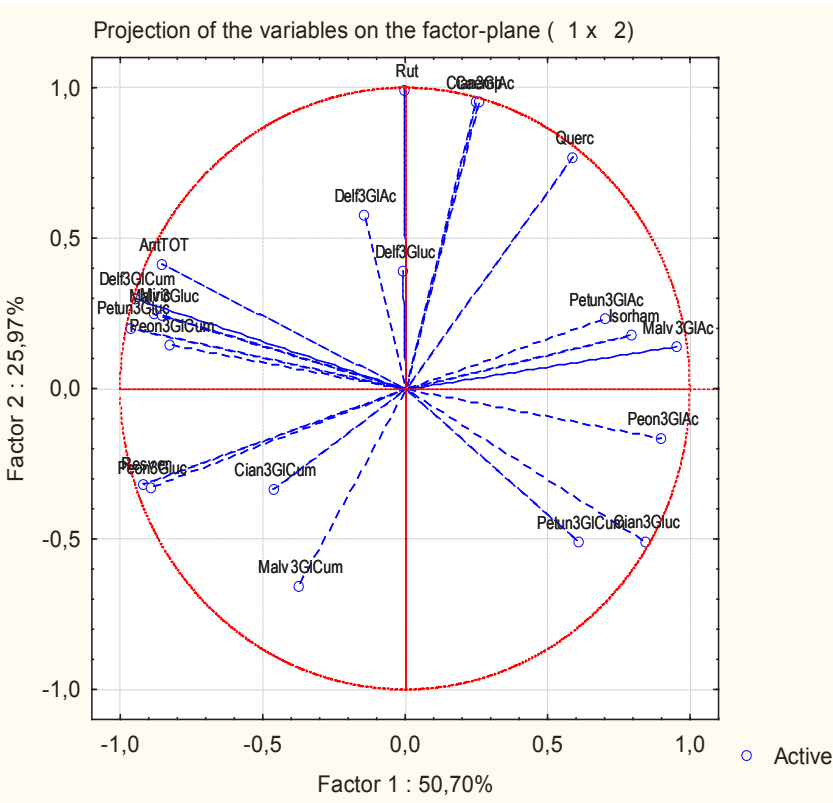

Figure 1B. Contribution of analytical parameters in variation of wines by principal component analysis.

FIGURE 1

Bahia (region with $1100 \mathrm{~m}$ of altitude); Pernambuco (region with $350 \mathrm{~m}$ of altitude); 14 and 15 (years of the experiment); R1 R2 and R3 (repetition of the analysis); Delf3Gluc Delphinidin 3-O-glucoside; Cian3Gluc Cyanidin 3-O-glucoside; Petun3Gluc Petunidin 3-O-glucoside; Malv3Gluc Malvidin 3-O-glucoside; Peon3GlAc Peonidin 3-O-acetylglucoside; Petun3GlAc Petunidin 3-O-acetylglucoside; Cian3GlAc Cyanidin 3-O-acetylglucoside; Delf3GlAc Delphinidin 3-O-acetylglucoside; Malv3GlAc Malvidin 3-O-acetylglucoside; Peon3GlCum Peonidin 3-O-coumarylglucoside; Petn3GlCum Petunidin 3-O-coumarylglucoside; Delf3GlCum Delphinidin 3-O-coumarylglucoside; Malv3GlCum Malvidin 3-O-coumarylglucoside; AntTOT Total anthocyanins; Quer Quercetin; Isorhm Isorhamnetin; Rut Rutin; Myr Myricetin.

harvests (Fig. 2) explained $85.35 \%$ of the total variability (PC1 x PC2). Principal component 1 (PC1) explained $39.02 \%$ while $\mathrm{PC} 2$, on the $\mathrm{Y}$ axis, illustrated $46.33 \%$ of the mathematical model. It is possible to observe that the altitude effects followed by the harvest date influence, are well representative. The first component $(\mathrm{PC} 1)$ divided the treatments into two distinct groups, and on the positive side of PC1 (X-axis), wines from the low-altitude region and the negative ones were located at the highest altitude. The variables that are responsible for discrimination on the positive side of $\mathrm{PC} 1$ were: total tannins, polymeric tannins, $\mathrm{B} 23$ 'galate, $\mathrm{B} 1$, catechin and $\mathrm{C} 1$. While on the negative side of $\mathrm{PC} 1$ there is influence of the following parameters: monomeric tannins, oligomeric, gallocatechin, B2, B3, B2 3-gallate, T2, epicatechin 3-O-gallate, epigallocatechin, B1 3-O-gallate. The PC2 differentiated the wines in relation to the harvest year, located in the positive part of PC2, the wines from the harvest of 2015 discriminated due to higher concentrations for the $\mathrm{C} 1$, epigallocatechin and $\mathrm{B} 1$ 3-O-gallate. In the negative part, are the samples of the region of higher-altitude, with higher values for the other parameters. As can be verified the results of the PCA are consistent with the analyses presented in Table 3 . Through the PCA analysis it can be concluded that wines from the 2014 harvest had a higher tannin content than wines from the
2015 harvest, and wines from the region of $350 \mathrm{~m}$ altitude had higher concentrations of polymerized tannins than wines from the region at $1100 \mathrm{~m}$ altitude.

\section{Sensory analysis of the wines}

The result of the sensorial profile of the wines is described in Fig. 3 and in Table 4 the results of the average test of the notes on the attributes evaluated by the tasters. In the greater the distance of the center, the greater the intensity and the note assigned by the tasters to the attributes. It is observed that the wines are distinct from each other and that there is an influence of altitude and harvest in their sensorial characteristics, data confirmed by statistic of the notes attributed in the tests.

On the visual level, the Bahia wine, obtained higher grades for color (harvest of 2015, followed by 2014), limpidity, fluidity, with the exception of color intensity alone (Pernambuco wine, in 2015). Altitude wines obtained higher color scores, which coincides with color intensity analysis, and which can be explained by their high concentrations of anthocyanins (Table 2).

For the olfactory characteristics, the main aroma detected in all samples with high notes was fruity. But the wines of low-altitude also have as olfactory attribute, the floral (note 4.6), herbaceous (note 4.5), fruit (note 6.3) and 


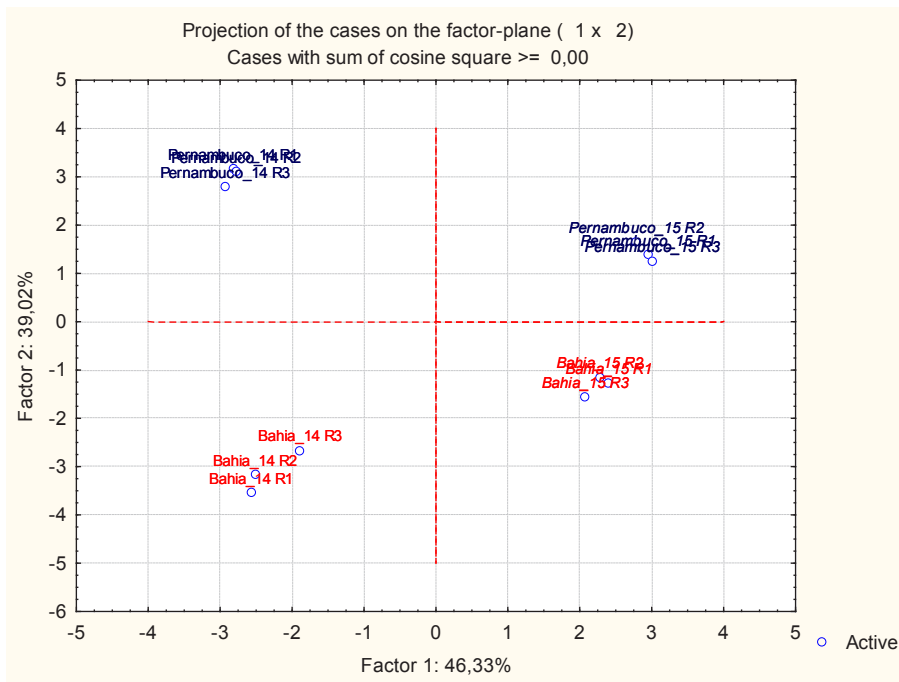

Figure 2A. Wines Syrah and regions.

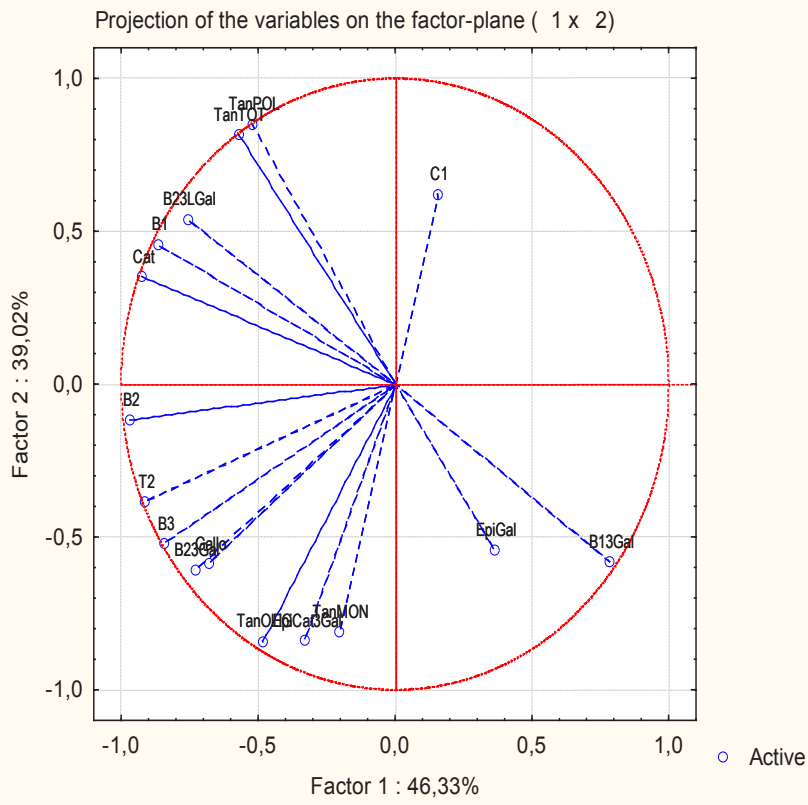

Figure 2B. Contribution of analytical parameters in variation of wines by principal component analysis.

\section{FIGURE 2}

Bahia (region with $1100 \mathrm{~m}$ of altitude); Pernambuco (region with $350 \mathrm{~m}$ of altitude); 14 and 15 (years of the experiment); R1, R2 and R3 (repetition of the analysis); Gall Gallocatechin; Cat Catechin; Epicat Epicatechin; Epigal Epigallocatechin; B1, B2 and B3 (Procyanidins dimer); B1 3 Gal B1 3-O-gallate, B2 3 Gal B2 3-O-gallate and B2 3LGal B2 3'-O-gallate (Procyanidin dimers gallate); Epicat_Gal Epicatechin 3-O-gallate; $\mathrm{C} 1$ and T2 (Procyanidins trimers); Tan MON monomeric tannins; Tan OLI oligomeric tannins; Tan POL polymeric tannins; Tan TOT Total tannins.

empireumatic aroma (note 5.1). Already the wines of highaltitude also obtained higher notes for the attribute spices. According to studies carried out by Geue et al. (2011) with Syrah wines from the hot and cold climate of Australia, in which they mentioned that the warm region wines had more fruity aromas and of the cold regions were described with notes of spices (mainly pepper).

Regarding the gustatory attributes, the wine of high altitude, in 2014, was characterized by higher notes for acidity (being according to the physicochemical analyzes, which also obtained a higher total acidity, Table 1), alcohol, bitterness, astringency, body and persistence. The sweetness attribute was higher in the wines of Pernambuco (2014), with 4.8 points, in the physical-chemical analysis, these wines also obtained higher values of residual sugar (Table 1).

There was no positive correlation between the note of the attribute astringency with the tannin content and tannin power in wines. Wines from the region of Bahia (harvest 2014) obtained a higher note, followed by the wines of Pernambuco also in the same harvest, with 5.3 and 4.7, respectively. Higher values for the Bahia wine samples followed by Pernambuco may be related to higher concentrations of total acidity, succinic acids (Table 1) and total flavanols (Table 3 ) in these wines. The perception of astringency results from complex phenolic profiles, as well as from other wine compounds the increase may be due, for example, the acidity of wine, that increasing the efficacy of bonding of polyphenols to salivary proteins (Perez-Maldonado et al., 1995); the organic acids, that have astringent properties in their own right (Lawless et al., 1996), which may result from $\mathrm{pH}$ mediated reduction in salivary viscosity (Nordbo et al., 1984) and the flavanols which occur esterified with gallic acid (Singleton \& Noble, 1976), conjugated with anthocyanins (Singleton \& Trousdale, 1992) or free form (Ricardo-da-Silva et al., 1991b).

The bitterness attribute obtained higher scores in wines from the Bahia region (year 2014), which may be related to a higher concentration of the flavonoids (Table 2) and monomeric tannins (Table 3) in the wines, the flavonoids phenols are the main cause of bitterness in wine (Singleton, 1995).

The sensory composition of the wine is complex, due to the quantity and importance of each compound involved. In this study, the characterization was influenced by factors such as grape composition in each region and harvest season.

\section{CONCLUSIONS}

The altitude and its peculiarities (day/night thermal amplitude, precipitation and solar radiation) had a significant effect on the chemical composition, principally in relation to the phenolic compounds and sensorial profile of the tropical wines of Northeast Brazil.

The low-altitude Syrah wines (Pernambuco) were characterized with high concentrations of tartaric acid, citric acid, potassium, quercetin, isorhamnetin, total flavonols, polymeric tannins and anthocyanins 3-O-acetylglucoside (petunidin and malvidin). 


\section{Brasilian Tropical Syrah wines (from Bahia and Pernambuco)}

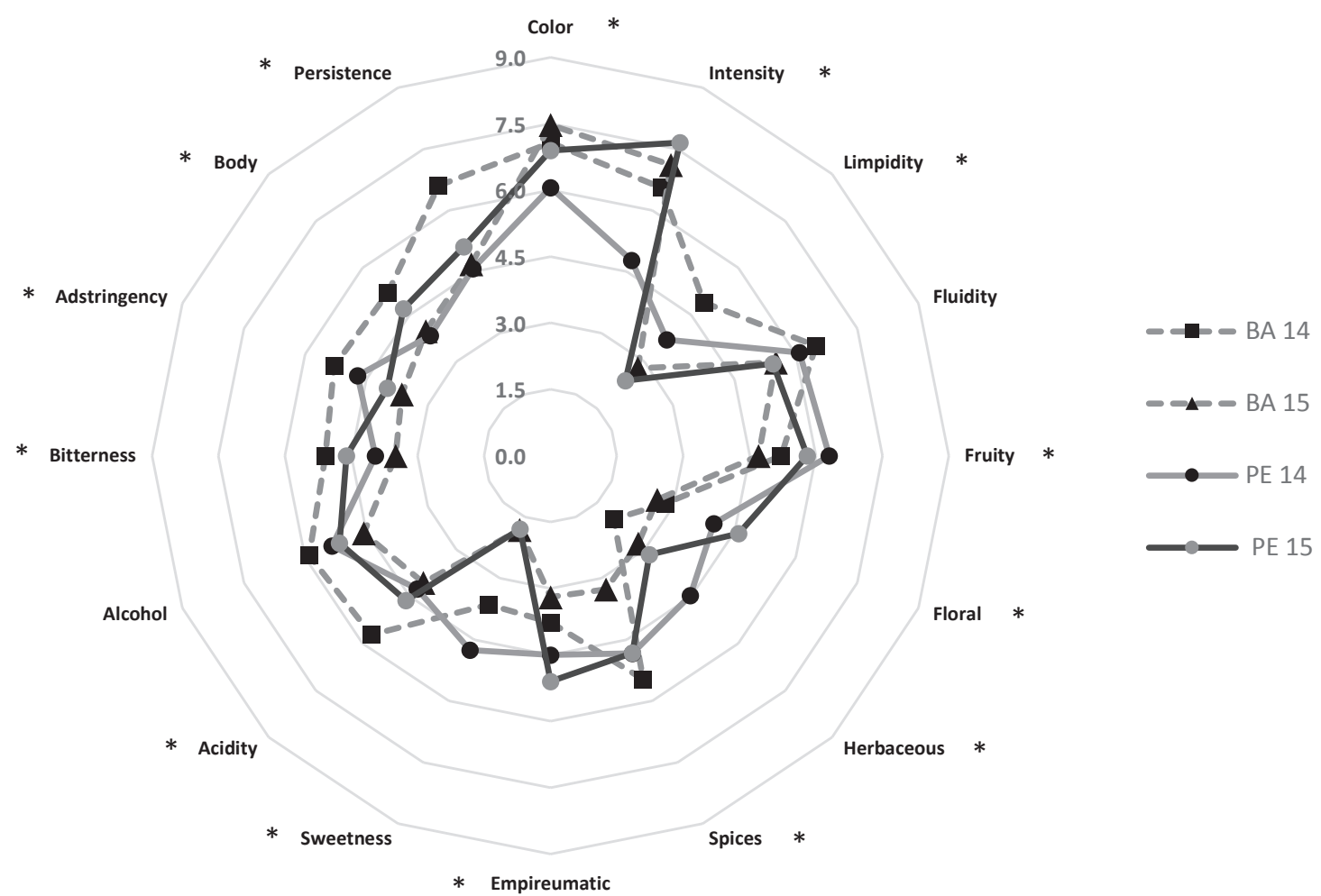

FIGURE 3

Influence of the region on the sensory profile of Brazilian tropical Syrah wines. BA 14 - Bahia state (1100 m altitude) year 2014; BA 15 - Bahia state (1100 m altitude) year 2015; PE 14 - Pernambuco state (350 m altitude) year 2014; PE 15 - Pernambuco state (350 m altitude) year 2015. * For most parameters significant statistical differences were observed.

(for more details, see Table 4)

TABLE 4

Descriptive analysis (0-10 scale) for the attributes of Syrah wines, from two tropical regions with different altitudes in Brazil (Bahia and Pernambuco regions).

\begin{tabular}{|c|c|c|c|c|c|}
\hline \multirow{2}{*}{$\begin{array}{l}\text { Region } \\
\text { Harvest }\end{array}$} & \multicolumn{2}{|c|}{ Bahia (1100 m altitude) } & \multicolumn{2}{|c|}{ Pernambuco (350 $\mathrm{m}$ altitude) } & \multirow{2}{*}{$\begin{array}{l}\text { ANOVA } \\
\text { (p-values) }\end{array}$} \\
\hline & 2014 & 2015 & 2014 & 2015 & \\
\hline \multicolumn{6}{|l|}{ Visual profile } \\
\hline Color & $7.1^{\mathrm{b}} \pm 0.9$ & $7.5^{\mathrm{a}} \pm 1.0$ & $6.1^{\mathrm{c}} \pm 0.8$ & $6.9^{\mathrm{b}} \pm 1.1$ & $* *$ \\
\hline Intensity & $6.6^{c} \pm 1.3$ & $7.1^{\mathrm{b}} \pm 1.3$ & $4.8^{\mathrm{d}} \pm 1.8$ & $7.7^{\mathrm{a}} \pm 1.3$ & $* * *$ \\
\hline Limpidity & $4.9^{\mathrm{a}} \pm 1.7$ & $2.8^{\mathrm{c}} \pm 2.0$ & $3.7^{\mathrm{b}} \pm 2.0$ & $2.4^{\mathrm{c}} \pm 1.7$ & $*$ \\
\hline Fluidity & $6.5^{\mathrm{a}} \pm 1.3$ & $5.5^{\mathrm{ab}} \pm 1.9$ & $6.1^{\mathrm{a}} \pm 1.1$ & $5.4^{\mathrm{ab}} \pm 1.5$ & n.s. \\
\hline \multicolumn{6}{|c|}{ Aromatic attributes } \\
\hline Fruity & $5.1^{b} \pm 1.8$ & $4.7^{\mathrm{c}} \pm 1.6$ & $6.3^{\mathrm{a}} \pm 1.9$ & $5.8^{\mathrm{b}} \pm 2.0$ & $*$ \\
\hline Floral & $2.8^{\mathrm{c}} \pm 1.9$ & $2.6^{\mathrm{c}} \pm 1.4$ & $4.0^{\mathrm{b}} \pm 1.6$ & $4.6^{\mathrm{a}} \pm 1.3$ & $* * *$ \\
\hline Herbaceous & $2.0^{\mathrm{d}} \pm 1.5$ & $2.8^{\mathrm{c}} \pm 2.7$ & $4.5^{\mathrm{a}} \pm 1.7$ & $3.2^{\mathrm{b}} \pm 2.2$ & $*$ \\
\hline Spices & $5.5^{\mathrm{a}} \pm 1.9$ & $3.3^{\mathrm{c}} \pm 1.8$ & $4.8^{\mathrm{b}} \pm 1.5$ & $4.8^{\mathrm{b}} \pm 1.3$ & $*$ \\
\hline Empireumatic & $3.8^{\mathrm{c}} \pm 1.3$ & $3.2^{\mathrm{d}} \pm 1.8$ & $4.5^{\mathrm{b}} \pm 1.6$ & $5.1^{\mathrm{a}} \pm 1.7$ & $*$ \\
\hline
\end{tabular}


TABLE 4 (CONTINUED)

\begin{tabular}{|c|c|c|c|c|c|}
\hline \multirow{2}{*}{$\begin{array}{l}\text { Region } \\
\text { Harvest }\end{array}$} & \multicolumn{2}{|c|}{ Bahia (1100 m altitude) } & \multicolumn{2}{|c|}{ Pernambuco (350 $\mathrm{m}$ altitude) } & \multirow{2}{*}{$\begin{array}{r}\text { ANOVA } \\
\text { (p-values) }\end{array}$} \\
\hline & 2014 & 2015 & 2014 & 2015 & \\
\hline \multicolumn{6}{|c|}{ Taste attributes } \\
\hline Sweetness & $3.6^{\mathrm{b}} \pm 1.8$ & $1.8^{\mathrm{c}} \pm 1.4$ & $4.8^{\mathrm{a}} \pm 1.5$ & $1.8^{\mathrm{c}} \pm 0.8$ & $* * *$ \\
\hline Acidity & $5.7^{\mathrm{a}} \pm 1.5$ & $4.1^{\mathrm{c}} \pm 1.8$ & $4.3^{c} \pm 1.3$ & $4.6^{\mathrm{b}} \pm 1.8$ & $* *$ \\
\hline Alcohol & $5.9^{\mathrm{a}} \pm 2.0$ & $4.6^{\mathrm{b}} \pm 1.4$ & $5.3^{\mathrm{ab}} \pm 2.1$ & $5.2^{\mathrm{ab}} \pm 1.3$ & n.s. \\
\hline Bitterness & $5.1^{\mathrm{a}} \pm 1.7$ & $3.5^{\mathrm{c}} \pm 1.9$ & $4.0^{\mathrm{bc}} \pm 1.6$ & $4.6^{\mathrm{b}} \pm 2.2$ & $*$ \\
\hline Astringency & $5.3^{\mathrm{a}} \pm 1.3$ & $3.6^{\mathrm{c}} \pm 2.1$ & $4.7^{\mathrm{b}} \pm 1.8$ & $3.0^{\mathrm{c}} \pm 2.1$ & $*$ \\
\hline Body & $5.2^{\mathrm{a}} \pm 1.3$ & $4.0^{c} \pm 1.3$ & $3.8^{c} \pm 1.3$ & $4.7^{\mathrm{ab}} \pm 1.5$ & $*$ \\
\hline Persistence & $6.6^{\mathrm{a}} \pm 1.5$ & $4.7^{\mathrm{c}} \pm 1.7$ & $4.6^{c} \pm 0.7$ & $5.1^{\mathrm{b}} \pm 1.8$ & $*$ \\
\hline
\end{tabular}

* Means followed by the same letter in the lines did not differ by Tukey test at $5 \%(\mathrm{p} \leq 0.05)$. Standard deviation of triplicate analysis; n.s. (not significant); * (significant differences at a 95\% confidence level); ** (significant differences at a 99.9\% confidence level); *** (significant differences at a $99.99 \%$ confidence level).

The altitude of $1100 \mathrm{~m}$ (Bahia) provided wines with higher levels of succinic acid, total phenols, flavonoids, total and colored anthocyanins, ionization index of anthocyanins, total pigments, polymerized pigments, color intensity, monomeric and oligomeric tannins, trans-resveratrol, anthocyanins 3-O-glucoside (peonidin, petunidin and malvidin), three anthocyanins esterified with p-coumaric acid (peonidin, delphinidin and malvidin) and procyanidins B3, B1 3-O-gallate and Trimer 2.

Sensory attributes (spice, acidity, bitterness, astringency, body and persistence) are influenced by year of harvest, being the wine of the region of Bahia $(1100 \mathrm{~m})$ with highest values, in the year 2014. High scores to aromatic attributes (fruity, floral, herbaceous and empyreumatic) were obtained in $350 \mathrm{~m}$ altitude wines (Pernambuco), demonstrating an altitude effect, since there was the same behavior during the two years of study.

\section{LITERATURE CITED}

Adams, D.O. \& Scholz, R.C., 2008. Tannins - the problem of extraction. Proceedings of the 13th Australian Wine Industry Technical conference (Blair, R.J. et al. eds.), Australian Society for Viticulture and Oenology: Adelaide pp. 160-164.

Agatonovic-Kustrin, S., Hettiarachchi, C.G., Morton, D.W. \& Razic, S., 2015. Analysis of phenolics in wine by high performance thin-layer chromatography with gradient elution and high-resolution plate imaging. J. Pharm. Biomed. Anal. 102, 93-99.

Amerine, M.A. \& Ough, C.S., 1980. Methods for Analysis of Musts and Wines. Wiley, New York. pp. 246.

Andrade, R.H.S., Nascimento, L.S., Pereira, G.E., Hallwass, F. \& Paim A.P.S., 2013. Anthocyanin composition of Brazilian red wines and use of HPLC-UV-Vis associated to chemometrics to distinguish wines from different regions. Microchem. J. 110, 256-262.

Belmiro, T.M.C., Pereira, C.F. \& Paim, A.P.S., 2017. Red wines from South America: content of phenolic compounds and chemometric distinction by origin. Microchem. J., 133, 114-120.
Coulter, A.D., Godden, P. W. \& Petrorius, I, S., 2004. Succínic acid. Wine Ind. J. 19, 16-25.

Cunha, T.J.F., Petrere, V.G., Silva, D.J., Mendes, A.M.S., Melo, R.F. de, Oliveira Neto, M.B. de, Silva, M.S.L. \& Alvarez, I.A., 2010. Principais solos do semiárido tropical brasileiro: caracterização, potencialidades, limitações, fertilidade e manejo. Semiárido brasileiro: pesquisa, desenvolvimento e inovação. Petrolina: Embrapa Semiárido. pp. 50-87.

Curvelo-Garcia, A.S. \& Barros, P., 2015. Química enológica- métodos analíticos. Avanços recentes no controlo da qualidade de vinhos e de outros produtos vitivinícolas. Editora Publindústria, edições técnicas, Portugal.

Cruz-Rus, E., Botella, M.A., Valpuesta, V. \& Gomez-Jimenez, M.C., 2010. Analysis of genes involved in ascorbic acid biosynthesis during growth and ripening of grape berries. J. Plant Physiol. 167, 739-748.

Dallas, C., Ricardo-da-Silva J.M. \& Laureano, O., 1996. Products formed in model wine solutions involving anthocyanins, procyanidin B2 and acetaldehyde. J. Agric. Food Chem. 44, 2402-2407.

DeBolt, S., Cook, D.R. \& Ford, C.M., 2006. L-Tartaric acid synthesis from vitamin $\mathrm{C}$ in higher plants. Proceedings of the National Academy of Sciences, 103, 5608-5613.

De Freitas, V. \& Mateus, N., 2001. Structural features of procyanidin interactions with salivary proteins. J. Agric. Food Chem. 49, 940-945.

Embrapa Solos. 2006. Solos do Nordeste brasileiro. Site: http://www.uep. cnps.embrapa.br/solos/pe/lagoagrande.pdf Accessed in 23/07/2018.

Fang, F., Li, J-M, Zhang, P., Tang, K., Wang, W., Pan, Q-H \& Huang, W-D., 2008. Effects of grape variety, harvest date, fermentation vessel and wine ageing on flavonoid concentration in red wines. Food Res. Int. 41, 53-60.

Fei He, Mu L., Yan G.-L., Liang N.-N., Pan Q.-H., Wang J., Reeves M.J. \& Duan. C.-Q., 2010. Biosynthesis of anthocyanins and their regulation in colored grapes. Molecules, 12, 9057-9091.

Fernández, V., Berradre, M., Sulbarán, B., Rodríguez, O. G. \& Peña, J., 2009. Chemical characterization and mineral content in Venezuelan commercial wines. Rev. Fac. Agron. (LUZ) 26, 382-397.

Geue, J.P., Bramley, B.R., Jeffery, D.W. \& Francis, I.L., 2011. In Proceedings of the 14th Australian Wine Industry Technical Conference; Blair, R., Lee, T., Pretorius, S., Eds.; pp. 317. 
Granato, D., Katayama, F.C.U. \& Castro, I.A., 2010. Assessing the association between phenolic compounds and the antioxidant activity of Brazilian red wines using chemometrics. Food Sc. Technol. 43, 1542 - 1549

Granato, D., Katayama, F.C.U. \& Castro, I.A., 2011. Phenolic composition of South American red wines classified according to their antioxidant activity, retail price and sensory quality. Food Chem. 129, 366-373.

Glories, Y. \& Saucier, C., 2000. Tannin evolution from grape to wine. Effects on wine taste. In 50th ASEV Anniversary Annual Meeting; Ratz, J., Ed.; ASEV: Davis, CA.

Gutiérrez, I.H., Lorenzo, E. S. \& Espinosa, A.V., 2005. Phenolic composition and magnitude of copigmentation in young and shortly aged red wines made from the cultivars, Cabernet Sauvignon, Cencibel and Syrah. Food Chem. $92,269-283$

Hanlin, R.L., Hrmova, M., Harbertson, J.F. \& Downey, M.O., 2010. Review: Condensed tannin and grape cell wall interactions and their impact on tannin extractability into wine. Aust. J. Grape Wine 16, 173-188.

Iland, P.G. \& Coombe, B.G., 1988. Malate, tartrate, potassium, and sodium in flesh and skin of Shiraz grapes during ripening: Concentration and compartmentation. Am. J. Enol.Vitic. 39, 71-76.

ISO (International Organization for Standardization). 1977. Sensory Analysis: apparatus - wines - tasting glass. In: Sensory analysis. ISO 3591.

Jirayus, W., Kanok-Orn, I. \& Korakod, I., 2007. Phenolic compounds and antioxidative properties of selected wines from the northeast of Thailand. Food Chem. 104, 1485-1490.

Kramling, T.E. \& Singleton V.L., 1969. An estimate of the non-flavanoid phenol in wines. Am. J. Enol.Vitic. 20, 86-92.

La Torre, G.L., Saitta, M., Vilasi, F., Pellicanò, T. \& Dugo, G., 2006 Direct determination of phenolic compounds in Sicilian wines by liquid chromatography with PDA and MS detection. Food Chem. 94, 640-650.

Lawless, H.T., Horne, J. \& Giasi, P., 1996. Astringency of organic acids is related to $\mathrm{pH}$. Chem. Senses. 21, 397-403.

Leeuw, R.V., Kevers, C., Pincemail, J., Defraigne, J.O. \& Dommes, J., 2014 Antioxidant capacity and phenolic composition of red wines from various grape varieties: Specificity of Pinot Noir. J. Food Compos. Anal. 36, 40-50.

Li Z., Pan Q., Jin Z., Mu L. \& Duan C., 2011. Comparison on phenolic compounds in Vitis vinifera L. cv. Cabernet Sauvignon wines from five wine-growing regions in China. Food Chem. 125, 77-83.

Lima, L.L.A., Pereira, G.E. \& Guerra, N.B., 2011. Physicochemical characterization of tropical wines produced in the Northeast of Brazil. Acta Hortic. 910, 131-134.

Liang, N.-N., He, F., Bi, H.-Q., Duan, C.-Q., Reeves, M.J. \& Wang, J., 2012. Evolution of flavonols in berry skins of different grape cultivars during ripening and a comparison of two vintages. Eur. Food Res. Technol. 235, 1187-1197.

Lucena, A.P.S., Nascimento, R.J.B., Maciel, J.A.C., Tavares, J.X., BarbosaFilho, J.M. \& Oliveira, E.J., 2010. Antioxidant activity and phenolics content of selected Brazilian wines. J. Food Compos. Anal. 23, 30-36.

Monagas M., Núñez V., Bartolomé B. \& Gómez-Cordovés C., 2003. Anthocyanin-derived pigments in Graciano, Tempranillo and Cabernet Sauvignon wines produced in Spain. Am. J. Enol.Viticult. 54, 163-169.

Natividade, M.M.P., Corrêa, L.C., Souza, S.V.C., Pereira, G.E. \& Lima, L.C.O., 2013. Simultaneous analysis of 25 phenolic compounds in grape juice for HPLC: Method validation and characterization of São Francisco Valley samples. Microchem. J. 110, 665-674.

Nordbo, H., Darwish, S. \& Bhatnagar, R. S., 1984. Salivary viscosity and lubrication: influence of $\mathrm{pH}$ and calcium. Scand. J. Dent. Res. 92, 306-314.
O.I.V. 2014. Recueil des methodes internacionales d'analyse des vins et des moûts. Office Internacional de la vigne et du vin, Paris, France.

Oliveira, J. B., Silva, G. G., Araújo, A. J. B., Lima, L.L.A, Ono, E. O., Castro, R., Cruz, A., Santos, J. \& Pereira, G.E., 2012. Influence of the vintage, clone and rootstock on the chemical characteristics of Syrah tropical wines from Brazil. 9th Congrès International des Terroirs vitivinicoles, France.

Ortega-Regules, A., Romero-Cascales, I., Ros-García, J. M., López-Roca, J. M. \& Gómez-Plaza, E., 2006. A first approach towards the relationship between grape skin cell-wall composition and anthocyanin extractability. Anal. Chim. Acta, 563, 26-32.

Padilha, C.V.S., Biasoto, A.C.T., Corrêa, L.C., Lima, M.S. \& Pereira, G.E., 2016. Phenolic compounds profile and antioxidant activity of commercial tropical red wines (Vitis vinifera L.) from São Francisco Valley, Brazil. J. Food Biochem. 41,1-9

Pereira, G.E., Soares, J.M., Guerra, C.C., Lira, M.M.P., Lima, M.V.D. de \& Santos, J.de O., 2007. Caractérisation de vins rouges tropicaux produits au Nord-Est du Brésil. In Proceedings of the 59th Congresso Alemão de Viticultura e 8th Simpósio Internacional Inovações em Enologia, StuttgartAlemanha.

Pereira, G.E., Santos, J. de O., Guerra, C.C. \& Alves, L.A., 2008a Evaluation of grape and wine quality according to harvest date, in a tropical region in Northeast Brazil. In: VIIème Congrès International des Terroirs Viticoles, Nyon-Suisse.

Pereira, G. E. \& Bassoi, L. H., 2008b. Production of Syrah wines in tropical conditions of northeast Brazil. In: International Syrah Symposium. France, Anais.pp 45-49.

Pereira, G.E., Araújo, A.J.B., Santos de O., J., Oliveira, S.V., Nascimento, R.L., Quintino, C., Vanderlinde, R. \& Lima, L.L.A., 2011. Chemical and aromatic characteristics of Brazilian tropical wines. II International Symposium on Tropical Wines, Brazil.

Perez-Maldonado, R. A., Norton, B. W. \& Kerven, G. L., 1995. Factors afecting in vitro formation of tannin-protein complexes. J. Sci. Food Agric. 69, 291-298.

Revilla, E., Alonso, E. \& Kovac, V., 1997. The Content of Catechins and Procyanidins in Grapes and Wines as Affected by Agroecological Factors and Technological Practices. Wines, chapter 7, 69-80.

Ribéreau-Gayon P., 1970. Le dosage des composés phénoliques totaux dans les vins rouges. Anal. Chim. 52, 627-631.

Ribéreau-Gayon, P., 1973. Interprétation chimiques de la couleur des vins rouges. Vitis. 12, 119-142.

Ribéreau-Gayon, P., Dubourdieu, D., Donèche, B. \& Lonvaud, A., 2006. ( $2^{\text {nd }}$ ed) Handbook of Enology: the microbiology of wine and vinifications, John Wiley \& Sons, Chichester, UK.

Ricardo-da-Silva, J.M., Rosec J.P., Bourzeix M. \& Heredia, N., 1990. Separation and quantitative determination of grape and wine procyanidins by high performance reversed phase liquid chromatography. J. Sci. Food Agric. 53, 85-92.

Ricardo-da-Silva, J.M., Rigaud, J., Cheynier, V., Cheminat, A. \& Moutounet, M., 1991a. Procyanidin dimers and trimers from grape seeds. Phytochem. $30,1259-1264$

Ricardo-da-Silva, J.M., Cheynier, V., Souquet, J. M. \& Moutounet, M., 1991b. Interaction of grape seed procyanidins with various proteins in relation to wine fining. J. Sci. Food Agric. 57, 111-125.

Ricardo-da-Silva, J.M., Belchior, A.P., Spranger, M.I. \& Bourzeix, M., 1992. Oligomeric procyanidins of three grapevine varieties and wines from Portugal. Sci.aliments 12, 223-237. 
Rigaud, J., Pérez-Ilzarbe, J., Ricardo-da-Silva, J. M. \& Cheynier, V., 1991. Micro method for the identification of proanthocyanidin using thiolysis monitored by high performance liquid chromatography. J. Chromatogr. 540, 401-405.

Roggero, J.P., Coen, S. \& Ragonnet, B., 1986. High performance liquid chromatography survey on changes in pigment content in ripening grapes of Syrah. An approach to anthocyanin metabolism. Am. J. Enol.Vitic. 37, $77-83$

Satisha, J., Dasharath, P.O., Amruta, N.V., Smita, R.M., Ajay K.S. \& Ramhari G.S., 2013. Influence of canopy management practices on fruit composition of wine grape cultivars grown in semi-arid tropical region of India. Afr. J. Agric. Res.26, 3462-3472

Singleton, V.L. \& Noble, A.C., 1976. Wine flavor and phenolic substances. In: 26th Symposium, Series: Phenolic, sulfur and nitrogen compounds in food Favours, Washington, USA, pp. 47-70.

Singleton, V.L., 1995. Maturation of wines and spirits: comparisons, facts, and hypotheses. Am. J. Enol.Vitic. 46, 98-112.

Singleton, V.L. \& Trousdale, E.K., 1992. Anthocyanin-tannin interactions explaining differences in polymeric phenols between white and red wines. Am. J. Enol.Vitic. 43, 63-70.

Soares, J.M. \& Leão, P.C.S., 2009. A vitivinicultura no semiárido brasileiro. Brasília: Embrapa Informação Tecnológica; Petrolina: Embrapa Semiárido. Somers, T. C., 1971. The polymeric nature of wines pigments. Phytochem. $10,2175-2186$.

Somers, T.C. \& Evans, M.E., 1977. Spectral evaluation of young red wines: anthocyanin equilibria, total phenolic, free and molecular $\mathrm{SO}_{2}$,"chemical age". J. Sci. Food Agric. 28, 279-287.

Sun, B.S., Leandro, M.C., Ricardo-da-Silva, J.M. \& Spranger, M.I., 1998a. Separation of grape and wine proanthocyanidins according to their degree of polymerisation. J. Agric. Food Chem. 46, 1390-1396.

Sun, B.S., Ricardo da Silva, J.M. \& Spranger, M.I., 1998b. Critical factors of the vanillin assay for catechins and proanthocyanidins. J. Agric. Food Chem. 46, 4267-4274.
Sun, B., Ricardo-da-Silva, J.M. \& Spranger, M.I., 2001. Quantification of catechins and proanthocyanidins in several portuguese grapevine varieties and red wines. Cienc. Tec. Vitivinic. 16, 26-34

Tauchen, J., Marsik P., Kvasnicova, M., Maghradze, D., Kokoska, L., Vanek T. \& Landa, P., 2015. In vitro antioxidant activity and phenolic composition of Georgian, Central and West European wines. J. Food Compos. Anal. 41, 113-121.

Themelis, D.G., Tzanavaras, P.D., Anthemidis, A.N. \& Stratis, J. A., 1999. Direct, selective flow injection spectrophotometric determination of calcium in wines using methylthymol blue and an on-line cascade dilution system. Anal. Chim. 402, 259-266.

Timberlake, C.F. \& Bridle, P., 1976. The effect of processing and other factors on the colour characteristics of some red wines. Vitis. 15, 37-49.

Tonietto, J. \& Carbonneau, A., 1999. Análise mundial do clima das regiões vitícolas e de sua influência sobre a tipicidade dos vinhos: a posição da viticultura brasileira comparada a 100 regiões em 30 países. Anais: 9th Congresso Brasileiro de Viticultura e Enologia, Embrapa Uva e Vinho, Bento Gonçalves, Brasil, pp.75-90.

Tonietto, J. \& Pereira, G. E., 2011. The development of the viticulture for a high quality tropical wine production in the world. In: 17th International Symposium of the Group of International Experts of Vitivinicultural Systems for Cooperation, Asti. Proceedings. Asti: Le Progrès Agricole et Viticole, pp. 25-28.

Vidal, S., Courcoux, P., Francis, L., Kwiatkowski, M., Gawel, R., Williams, P., Waters, E.J. \& Cheynier, V., 2004. Use of an experimental design approach for evaluation of key wine components on mouth-feel perception. Food Qual. Prefer. 15, 209-217.

Walker, R.R., Clingeleffer, P.R., Kerridge, G.H., Rühl, E.H., Nicholas, P.R. \& Blackmore, D.H., 1998. Effects of the rootstock Ramsey (Vitis champini) on íon and organic acid composition of grapes and wine, and on wine spectral characteristics. Aust. J. Grape Wine 4, 100-110.

Zeng, L., Teissèdre, P. \& Jourdes M., 2016. Structures of polymeric pigments in red wine and their derived quantification markers revealed by high-resolution quadrupole time-of-flight mass spectrometry. Rapid Commun. J. Mass Spectrom. 30, 81-88. 